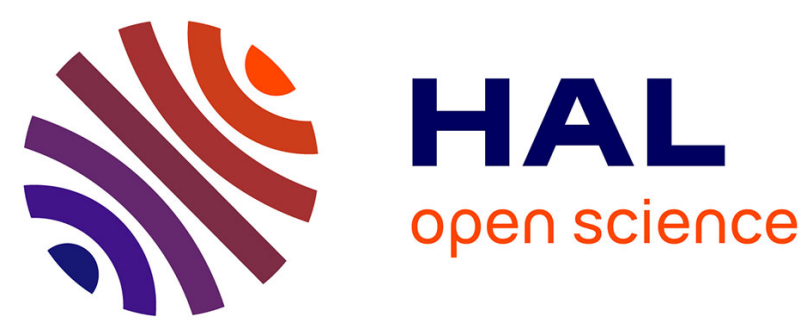

\title{
Impact of incipient weathering on uranium migration in granitic waste rock piles from former $U$ mines (Limousin, France)
}

\author{
A. Kanzari, M. Gerard, F. Boekhout, L. Galoisy, G. Calas, M. Descostes
}

\section{To cite this version:}

A. Kanzari, M. Gerard, F. Boekhout, L. Galoisy, G. Calas, et al.. Impact of incipient weathering on uranium migration in granitic waste rock piles from former $U$ mines (Limousin, France). Journal of Geochemical Exploration, 2017, 183, pp.114-126. 10.1016/j.gexplo.2017.08.010 . hal-01596042

\section{HAL Id: hal-01596042 https://hal.sorbonne-universite.fr/hal-01596042}

Submitted on 27 Sep 2017

HAL is a multi-disciplinary open access archive for the deposit and dissemination of scientific research documents, whether they are published or not. The documents may come from teaching and research institutions in France or abroad, or from public or private research centers.
L'archive ouverte pluridisciplinaire HAL, est destinée au dépôt et à la diffusion de documents scientifiques de niveau recherche, publiés ou non, émanant des établissements d'enseignement et de recherche français ou étrangers, des laboratoires publics ou privés. 


\section{Accepted Manuscript}

Impact of incipient weathering on uranium migration in granitic waste rock piles from former U mines (Limousin, France)

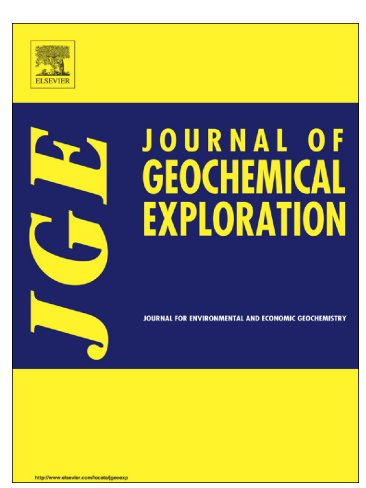

A. Kanzari, M. Gérard, F. Boekhout, L. Galoisy, G. Calas, M. Descostes

PII: S0375-6742(16)30350-8

DOI: doi: $10.1016 /$ j.gexplo.2017.08.010

Reference: GEXPLO 5979

To appear in: Journal of Geochemical Exploration

Received date: 22 November 2016

Revised date: \#\#\#REVISEDDATE\#\#\#

Accepted date: 26 August 2017

Please cite this article as: A. Kanzari, M. Gérard, F. Boekhout, L. Galoisy, G. Calas, M. Descostes, Impact of incipient weathering on uranium migration in granitic waste rock piles from former U mines (Limousin, France), Journal of Geochemical Exploration (2017), doi: 10.1016/j.gexplo.2017.08.010

This is a PDF file of an unedited manuscript that has been accepted for publication. As a service to our customers we are providing this early version of the manuscript. The manuscript will undergo copyediting, typesetting, and review of the resulting proof before it is published in its final form. Please note that during the production process errors may be discovered which could affect the content, and all legal disclaimers that apply to the journal pertain. 
Impact of incipient weathering on uranium migration in granitic waste rock piles from former U mines (Limousin, France)
A. Kanzaria, M. Gérarda, F. Boekhouta,, L. Galoisya, G. Calasa, M. Descostesb

anstitut de Minéralogie, de Physique des Matériaux, et de Cosmochimie (IMPMC), Sorbonne Universités, UPMC Univ Paris 06, UMR CNRS 7590, IRD UMR 206, 4 place Jussieu, F-75005, Paris, France

bAREVA Mines, R\&D Dpt, Paris la Défense, France.

*Present Address: Geologisch-Paläontologisches Institut, Correnstraße 24, 48149 Münster.

Corresponding authors: Martine GERARD martine.gerard@impmc.upmc.fr (Tel: 0033(0) 1442750 44); Aisha KANZARI aisha.kanzari@impmc.upmc.fr (Tel: 0033(0) 144 $272441)$. 


\section{Abstract}

This study investigates the impact of incipient weathering on uranium (U) migration at the surface of granitic waste rock piles from former $U$ mines in Limousin (France) operated half a century ago. We used a multi-scale mineralogical and geochemical approach to evaluate the impact of incipient weathering on uranium mobility in a chaotic waste rock pile. The surficial part of five former mines located in the "La Crouzille" and "La Creuse" mining districts was investigated. Four groups of samples were defined based on field observations and mineralogy, granites, lamprophyres, hydrothermally altered rocks and weathering products. Petrology, mineralogy and geochemistry investigations show the importance of mineralogical and geochemical transformations during incipient weathering over a few decades. The Chemical Index of Alteration (CIA) is successfully used to assess the weathering state of samples in the waste rock pile chaotic deposit. The mean CIA value is around 60 for unweathered/incipiently weathered granites whereas highly weathered samples have $\mathrm{CIA}$ around 70. This means that no significant major element loss occurs in the granitic rocks suffering incipient weathering. Various micron-size secondary $U$ minerals consist in a large diversity of oxidized uranyl minerals (uranophane, uranyl sulfate, curite, autunite and other uranyl phosphates), with dominant uranyl phosphates, indicating local $U$ mobility in the waste rock pile. Autunites micromorphology indicates different degrees of weathering of the samples in which it crystallizes. $U$ is primarily concentrated in the clay fraction $(<2 \mu \mathrm{m})$, associated with secondary minerals from granite alteration (clay minerals such as smectite and vermiculite, Fe-oxides and phosphate minerals) and, to a limited extent, relict primary minerals. These weathering products contribute to $U(V I)$ stabilization under oxidizing conditions. 


\section{Introduction}

Post-mining environmental monitoring has become an important part of the mininglife cycle (Jamieson 2015). In Western Europe, granitic intrusions were sites of intense mining activity in the 20th Century. In France, out of nearly 250 former $U$ mining sites, 50 are located in granitic massifs of the Limousin region, which hosts $57 \mathrm{Mt}$ of waste rocks (AREVA 2004). With a high specific surface, granitic waste rocks suffer enhanced weathering rates compared to regular outcropping granites. Recent interest has arisen concerning the environmental impact of granites, among which the sorption of uranium on granite for modeling high-level radioactive waste geological repositories (Lee et al. 2011; Jin et al. 2016). These works showed that, in the $\mathrm{pH}$ range $4-9, \mathrm{U}(\mathrm{VI})$ sorption increases up to $90 \%$ within $72 \mathrm{~h}$. Investigation of the environmental impact of uranium released by the industrial processing of granitic materials (scraps, water and slurries) also shows modification of $U$ speciation with increasing pH (Guillén et al. 2014). In addition, granite alteration studies by column acid leaching have demonstrated that weathering affects $U$ distribution (Guthrie and Kleeman 1986). A broad range of fields of environmental importance is concerned by granite weathering. Understanding the processes governing $U$ migration under these conditions is thus important to model source terms for a potential U environmental impact.

Granite weathering has been extensively studied in natural regoliths (Gilkes et al. 1973; Nesbitt and Young 1989; White and Brantley 1995; Braga et al. 2002; Takaya 2014; Scarciglia et al. 2016) and in monitored waste rock piles (Smith et al. 2013). The weathering rate of granite primarily depends on the weathering rate of its least stable minerals, biotite and plagioclase (Gilkes et al. 1973; White and Brantley 1995; Takaya 2014) and incipient weathering is mainly controlled by sulfide oxidation and $\mathrm{Al}$ and Fe-oxyhydroxide precipitation (Smith et al. 2013). The weathering intensity is quantified by several weathering indexes (Price and Velbel 2003). Among these, the "Chemical Index of Alteration" (ClA), defined by the ratio $\mathrm{Al}_{2} \mathrm{O}_{3} /\left(\mathrm{Al}_{2} \mathrm{O}_{3}+\mathrm{CaO}+\right.$ $\mathrm{Na}_{2} \mathrm{O}+\mathrm{K}_{2} \mathrm{O}$ ) (Nesbitt and Young 1989; Scarciglia et al. 2016) is frequently used to assess the weathering state of basaltic or granitic regoliths. It is a good proxy of continental crust weathering because it focuses on feldspar alteration, one of the most common minerals of the continental crust. 
Field based studies show the liberation of potential contaminants of concern (including $U$ ) from waste rocks from former $U$ mines during exposure to weathering under oxidizing conditions after a few decades (Tran et al. 2003; Kipp et al. 2009; Parbhakar-Fox et al. 2014; Cabral Pinto et al. 2014; Neiva et al. 2016). These studies highlight the local mobility of $U(V I)$ and its sorption on nano/micro-divided weathering minerals, such as clay minerals or Fe-oxides, or U(VI) sequestration by phosphate minerals. In natural regolith profiles, similar trends are observed: trace elements, including $\mathrm{U}(\mathrm{VI})$, are found along with phosphate minerals, clay minerals and Fe-oxides (Jerden et al. 2003; Taboada et al. 2006; Regenspurg et al. 2010). Despite the diversity of $U(\mathrm{VI})$ minerals, when phosphate is present in natural regoliths, $U$ bearing phosphate minerals are predominant (Jerden et al. 2003; Jerden and Sinha 2003; Jerden and Sinha 2006; Knox et al. 2006). U mobility is determined using various multi-scale approaches: from the field scale, identifying faulted structures responsible for $U$ re-concentration after hydrothermal episodes (Lespinasse and Cathelineau 1990) to the molecular scale, focusing on $U$ speciation (Morris et al. 1996; Allard et al. 1999; Kelly 2010; Morin et al. 2016).

A preliminary study (Boekhout et al. 2015) was performed on a trench dug in a granitic waste rock pile in the former Vieilles Sagnes uranium mine (Limousin, France), to evaluate the feasibility of our approach. The present study focuses on surficial incipient weathering at the very surface of five granitic waste rock piles of two former major U mining districts; "La Crouzille" and "La Creuse", Limousin, France (International Atomic Energy Agency 2009). This region is one of the largest vein-type uranium districts in Europe, and produced $23,300+U$ at an average grade of $0.2 \%$, between 1948 and 1995, resulting in $57 \mathrm{Mt}$ of granitic waste rocks that were left on site and partly re-vegetated (IRSN 2007). Previous environmental studies in nearby areas have demonstrated uranium mobility and its accumulation in certain levels of peat soils (up to $12000 \mathrm{ppm}$ ) by precipitation of colloids of $\mathrm{Fe}, \mathrm{Al}$ and OM or P-Al-Fe-Si (Wang et al. 2013; Leermakers et al. 2016). In the alpine region (Europe), natural soils arising from granite concentrate up to $4000 \mathrm{ppm}$ of $U$, despite the absence of mining activity in the area (Regenspurg et al. 2010). Weathering products of granite limit $U$ migration by sorption on Fe-oxyhydroxides (Leermakers et al. 2016) and clay minerals. 
The formation of uranyl phosphates is also observed (Boekhout et al. 2015). These phosphates are an efficient trap for uranium sequestration (Munasinghe et al. 2015).

The present study investigates $U$ migration in the surficial part ( 5 to $30 \mathrm{~cm}$ deep) of 5 granitic waste rock piles from former $U$ mines in the Limousin region, France, with an intense mining activity, 24 to 66 years ago. The granitic boulders investigated $10 \mathrm{~cm}$ to $30 \mathrm{~cm}$ large) present, from the rim to the core, incipient weathering features and show the influence of the previous geological history and the vegetation development. CIA parameters show coherent weathering trends from the granitic blocks to the underlying technosoil. Incipient weathering is related with CIA values between 55 and 65, whereas highly weathered samples have CIA around 70. Mechanical and chemical alteration of waste rock piles affects the soils and peat soils downslope. We discuss the mobilization of uranium, the first trapping processes associated to mineralogical and geochemical transformations and the preferential occurrence of specific secondary U minerals, such as uranyl phosphates.

\section{Materials and methods}

\subsection{Site description and sampling}

Fifty years of mining activity in vein-type granite-hosted $U$ deposits in Limousin resulted in 15 to $30 \mathrm{~m}$ high waste rock piles of dominantly granitic boulders $10 \mathrm{~cm}$ to $1 \mathrm{~m}$ large), subject to weathering and partly re-vegetated (with ferns and $2-5 \mathrm{~m}$ high birch trees). We sampled the waste rock piles from 4 selected former mining sites in the "La Crouzille" former mining district (Limousin, France), located in the European Variscan belt, in a two-mica granite massif (International Atomic Energy Agency 2009). A brief description of the regional geological background is given in in Appendix A. Additionally, the waste rock pile of the Hyverneresse mine, in the "La Creuse" mining district, Limousin, France (located in the Millevaches granite, a distinct, though contemporary, two-mica granite massif) was sampled. Hyverneresse is located in a felsic facies, principally composed of leucogranite (Stussi and Cuney 1993). Granite mineralogy and petrology are similar in both the "La Crouzille" and "La Creuse", mining districts (Leroy 1984; Bonhomme et al. 1987). In both districts, the ore is mainly composed of uraninite, pitchblende and coffinite. 
Most waste rocks correspond to non-mineralized granites from overburden, extracted to access the ore veins. The average $U$ concentration in these granites is 20 ppm (Cuney 2014; lelsch et al. 2016), in agreement with the regional $U$ background of Limousin granites. These two-mica granites contain around $36 \%$ quartz, $27 \%$ albite, $27 \%$ orthoclase and $10 \%$ biotite and muscovite (Dahlkamp 1993). Hydrothermal episodes or supergene alteration induce neoformation of calcite and pyrite (Leroy 1978), jarosite and clay minerals (McLemore et al. 2006; Salama et al. 2016). A minor part of the waste rocks corresponds to low-grade ore below the "cutoff grade", with a bulk U concentration, from 100 to 300 ppm (IRSN 2007). This cut-off grade was assessed on a large volume, $0.4 \mathrm{~m}^{3}$ (AREVA 2004), whereas hand sampling concerns volumes $10^{3}$ times smaller, $0.4 \mathrm{dm}^{3}$. Therefore isolated samples may exceed the average cut-off value of 300 ppm.

Five post-mining sites were studied: Bellezane, Fanay, Hyverneresse, Margnac and Pény (Appendix B). Sampling was restricted to the surficial 5 to $30 \mathrm{~cm}$ of the waste rock piles. Piles can reach $20 \mathrm{~m}$ high, with a slope of 10 to $1000 \%$ (Table S1 in the supplementary material). The Pény and Hyverneresse slopes are steep (over $500 \%$ ) and vegetation is scarce (Fig. 1a, Fig. 1C). The Fanay slope (75 \%) is more vegetated (Fig. 1b). On the contrary the Bellezane slope (75\%) has no vegetation. Bellezane site is a former open pit mine, with walls showing lamprophyre intrusions (Fig. 1d). Lamprophyre and granite have similar chemical composition. Due to their microgranular texture, lamprophyres are more sensitive to weathering than granites (Rock 1984). In this paper surficial lamprophyre represents a reference of intense supergene alteration.

Sampling focused on samples with a high radiometric signal in order to get the highest $U$ concentration possible. The radiometric signal (dose rate) ranges from 0.3 $\mu S v . h^{-1}$ to $2.4 \mu S v . h^{-1}$. Fifty samples representative of the diversity in mineralogy, morphology, and weathering degrees were selected and sorted in four groups: (Table S2 in the supplementary material):

- Granites with apparent weak alteration (27 samples): samples are decimetric, hard blocks of granites with visible alteration features. Some have cracks and fractures, as well as color changes from fresh pink in the bulk to orange and 
brown at the boulder surface due to oxidation. Most blocks composing the waste rock pile belong to this category (Fig. 1a, b and c).

- Lamprophyres (4 samples): at the open pit mine of Bellezane, two different outcrops of lamprophyre dykes have been sampled at different levels of the wall of the mine (not from the pile). The deepest outcrop (10 $\mathrm{m}$ below surface) was partially affected by hydrothermal alteration (Fig. 1d). The surficial part of the dyke was affected by intense supergene alteration. Lamprophyre blocks are scarce in the waste rock pile and generally highly weathered. Therefore they were sampled in the wall-rock for a representative sampling.

- Hydrothermally altered rocks (8 samples) are divided in two sub-groups:

- a sub-group of friable coarse grained granite containing calcite (3 samples).

- a sub-group of hard fine grained rocks containing sulfides (5 samples) with a yellow coloration.

- Weathering products (15 samples) can be divided in 4 sub-groups:

- Arenization matrix of the weathered rim of the blocks is found as siltyclay weathering aureoles of submetric granitic blocks. Weathering associated with fracturing has led to the arenization of the waste rocks.

- Protosoils correspond to the incipient formation of centimetric sandysilty horizon at the surface of the waste rock pile associated with moss growth and located below birch trees mid slope of the pile.

- Technosoils are located on flat surfaces either at the top or at the bottom of the piles. They consist of a 10 to $20 \mathrm{~cm}$ thick silty-clayey brown soil with a variable humic fraction. They are eventually mixed with soil cover from the overburden, after site rehabilitation.

- Ferrihydrite-rich orange and muddy meter-wide pools form downslope. These pools, distinct from the rills, indicate a Fe migration and they are specific to the waste rock pile of Hyverneresse (Fig. 1c). 


\subsection{Analytical procedures}

XRD analyses were performed using an X'Pert Pro Panalytical diffractometer with $\mathrm{Ni}$ filtered CuKa radiation at $40 \mathrm{kV}$ and $40 \mathrm{~mA}$. All samples were ground with an agate mortar and pestle prior to bulk analyses. The $<2 \mu \mathrm{m}$ fraction was obtained by sizefractionation of bulk samples in deionized water according to Stoke's law. Disoriented powders of all samples were scanned from $3^{\circ}$ to $75^{\circ}(2 \theta)$ with a counting time of $520 \mathrm{~s}$ every $0.0167^{\circ}$, in an aluminum rotating sample-holder. For clay mineral identification, the $<2 \mu \mathrm{m}$ fractions were deposited by evaporation from deionized water on glass-disk holders. Oriented air-dried, glycolated and heated $\left(550^{\circ} \mathrm{C}\right.$ for 3 hours) samples were scanned from $3^{\circ}$ to $15^{\circ}$ with a counting time of $270 \mathrm{~s}$ every $0.0167^{\circ}$.

Dry granulometric separations were performed with a set of sieves $(1 \mathrm{~cm}, 2 \mathrm{~mm}, 63$ $\mu \mathrm{m}$ ) on 7 samples (Table S5). Wet granulometric separations of the "clay fraction" $<$ $2 \mu \mathrm{m}$ ) were performed on 9 bulk samples (Tables S4). $10 \mathrm{~g}$ of bulk sample was mixed with water and ultrasound for 10 minutes in order to separate agglomerated minerals. After $5 \mathrm{~h}$ sedimentation, in a total of $1000 \mathrm{ml}$ of water, the supernatant was siphoned out and centrifuged at $4000 \mathrm{rpm}$ for $60 \mathrm{~min}$. The dried sample is referred to as the "clay fraction" $(<2 \mu \mathrm{m})$, following the international nomenclature.

Thin sections were manufactured from the core of blocks 10 to $20 \mathrm{~cm}$ large. They were made at the Institut de Recherche pour le Développement (IRD), Bondy research center and studied with an optical microscope Olympus, BH-2.

Scanning Electron Microscopy (SEM) analyses were conducted with a Zeiss ULTRA55 with an acceleration voltage of $15 \mathrm{keV}$ and a working distance of $7.5 \mathrm{~mm}$. Micromorphological observations were made with secondary and backscattered electrons detectors, and an Energy Dispersive Spectroscopy (EDS) microprobe.

Chemical analyses were obtained by Inductively Coupled Plasma-Mass Spectrometry (ICP-MS) on an Agilent 7500 CX® at IRD Bondy Research center, for major elements (detection limits in ppm between brackets): $\mathrm{Na}(0.05), \mathrm{Mg}(0.05)$, $\mathrm{Al}(0.8), \mathrm{P}$ (0.02), K(0.2), $\mathrm{Ca}(0.45), \mathrm{Ti}(0.05), \mathrm{Fe}(0.9), \mathrm{Mn}(0.005)$; and trace elements (detection limits in ppb between brackets): $\mathrm{Ba}(2.5), \mathrm{Ce}(1.0), \mathrm{La}(0.5), \mathrm{Pb}(0.2), \operatorname{Th}(0.5)$, $U(2.5)$ and $\operatorname{Zr}(0.9)$. ICP-MS measurements were performed after multi-acid digestions $\left(\mathrm{HNO}_{3}-\mathrm{HF}-\mathrm{H}_{3} \mathrm{BO}_{3}\right)$. The $\mathrm{Si}$ volatile component is lost during the evaporation. International reference materials (GSN and MAN) were regularly measured for 
quantitative accuracy estimation. Values given are issued from three replicates to insure accuracy and precision of the data. For all trace elements the precision was below $5 \%$ (RSD).

Sulfur measurements were conducted by pyro-hydrolysis at the Institut de Physique du Globe de Paris (IPGP). Values are given +/- 0.01\%. Loss on Ignition (L.O.I) measurements were carried out according to Lechler and Desilets (1987) procedure for igneous rocks. Values are given $+/-0.1 \%$. The amount analyzed was extracted from $100 \mathrm{~g}$ of sample previously ground in order to get representative values.

\section{Results}

\subsection{Incipient weathering identification using mineralogical and geochemical tools}

\subsubsection{Waste rock mineralogy}

Micromorphology observations on thin sections (Fig. 2) and XRD mineralogy (Fig. S1 in the supplementary material) help determine the origin of the alteration (weathering, or hydrothermalism) within the four groups of samples (Table S2 in supplementary material):

1- Granites. The granitic group can be subdivided in two groups, depending on the alteration state: "no or low clay minerals content" and "significant clay minerals content". The clay minerals identified are chlorite (Fig. S1-la in the supplementary material) and/or kaolinite. Granitic samples show cemented mineral grains (Fig. 2a): quartz, mostly unweathered feldspars, partially weathered biotite, fresh muscovite and accessory minerals (zircons and monazites). Chlorite alteromorph after biotite (i.e. partial transformation of biotite minerals to chlorite, with conservation of the initial biotite's shape) indicates incipient weathering (Fig. 2b). Radiation aureoles evidence accessory radioactive minerals included in biotites such as zircons and monazites (Fig. 2b). Incipient weathering affects micas and feldspars with the formation of micrometric Fe-oxides veins (Fig. 2c).

2- Lamprophyres (Fig. S1-II in the supplementary material). The lower part of the lamprophyre dyke mineral assemblage (Fig. 1d) is composed of plagioclase, K- 
feldspar, quartz, smectite and chlorite with scarce micas and amphiboles (Fig. 2f and Fig. S1-II-d in the supplementary material). The matrix consists of clay minerals and Feoxides (Fig. 2f). In the surficial part of the same dyke, the occurrence of vermiculite, interstratified clay minerals and rare relicts of plagioclase indicates an intensely weathered state (Fig. S1-II-e f and $g$ in the supplementary material), observed in the most powdery part of the dyke.

3- Hydrothermally altered rocks. The calcite-rich rocks (Leroy 1978) are composed of calcite, smectite, rare biotite and muscovite (Fig. S1-III in the supplementary material). The most friable sample is the most altered, kaolinite occurrence suggests recent weathering. Sulfide-rich rocks contain quartz similar to an episyenite facies. Large areas $\left(600 \mathrm{\mu m}^{2}\right)$ of clay minerals and Fe-oxides occur in the matrix (Fig. $2 \mathrm{~d}$ ). They are affected by weathering down to the core of $20 \mathrm{~cm}$ blocks, as shown by clay mineral alteromorph after feldspar (Fig. 2e), pyrite dissolution figures (Fig. 3c) and jarosite neoformation (Fig. 3a) suggesting pyrite oxidation.

4- Weathering products (Fig. S1-I in the supplementary material). The mineral paragenesis of the granitic arena includes smectite, chlorite, kaolinite and interstratified clay minerals (FIG. S1-lb in the supplementary material) with relict primary minerals. Protosoil samples contain quartz, K-feldspars and plagioclases, micas, Fe-oxides, smectite, kaolinite (Fig. SI-IC in the supplementary material) and jarosite. Technosoils have a similar mineralogical signature, with a variable content of interstratified clay minerals and no or rare jarosite. They present a high content of organic matter, with an extreme example represented by a humic horizon, occurring at the bottom of the Fanay pile (Table S3 in the supplementary material). The ferrihydrite encountered in the pools is a 2-line ferrihydrite, with two broad bands corresponding to d-spacings of 1.5 and $2.5 \AA$.

Mineralogy along with micromorphology observations helps determine the weathering impact on the waste rock piles. In the coarse groundmass of the arena, dominant features are various clay minerals alteromorphs after biotites and feldspars. The micromass is dominated by neoformation of Fe-oxyhydroxides, jarosite and clay minerals. The oxidation of sulfides and subsequent Fe-migration are evidence of the oxidized state of the surficial part of the waste rock piles. 
Vegetation and a constant water regime induce rapid alteration of feldspar and delamination of biotite (Wongfun et al. 2013) associated with preferential leaching on the edge of the minerals. We observe that lichen frequently grows on the waste rocks here investigated. Entangled with the minerals of the weathered outer rim, lichen weakens the surface of the boulders (Fig. 3b). Roots of birch trees and ferns invading surficial fractures induce mechanical alteration and favor the development of protosoils. Therefore incipient weathering is increased in the vegetated piles.

\subsubsection{Geochemical trends}

The geochemical trends observed during incipient and further stages of weathering will be discussed as a function of the degree of chemical weathering, using the Chemical Index of Alteration,, (Nesbitt and Young 1989), calculated as:

$$
\mathrm{CIA}=\frac{\% \mathrm{Al}_{2} \mathrm{O}_{3}}{\% \mathrm{Al}_{2} \mathrm{O}_{3}+\% \mathrm{CaO}+\% \mathrm{NaO}+\% \mathrm{~K}_{2} \mathrm{O}} * 100
$$

$\mathrm{CIA}$ is widely applied to evaluate the chemical weathering intensity in weathering profiles and is used here to quantify the relative weathering intensity of our lamprophyre and granite samples, starting from typical CIA values between 55 and 65 for the least altered granites (Table S3 in the supplementary material) up to the "optimum weathered value" of 100 (Price and Velbel 2003). However, the Ca enrichment related to low temperature hydrothermal alteration precludes the comparison between weathered and hydrothermally altered granites. The most probable source of $\mathrm{Ca}$ is the convection circulation of meteoric waters induced by low temperature hydrothermalism. We have plotted the geochemical evolution of the waste rock piles in the $\left[\mathrm{Al}_{2} \mathrm{O}_{3}-\mathrm{K}_{2} \mathrm{O}-\left(\mathrm{CaO}+\mathrm{Na}_{2} \mathrm{O}\right)\right]$ diagram (Fig. 4) (Rollinson 2014). Because of their high Fe concentration, the samples from "ferrihydrite pools" were excluded from this analysis. Two main trends of weathering appear; one from an incipient to an intense weathering state (trend A), and a second from an intense weathering state towards a pure kaolinite pole (trend B). The geochemical evolution of the four groups of rocks will be discussed by combining $\mathrm{ClA}$ values with the trends observed in the $\left[\mathrm{Al}_{2} \mathrm{O}_{3}-\mathrm{K}_{2} \mathrm{O}-\left(\mathrm{CaO}+\mathrm{Na}_{2} \mathrm{O}\right)\right]$ diagram. 
Granites: most samples composing the waste rock piles are two-mica granites, with various alteration states. The mean $\mathrm{ClA}$ value is around 60 for unweathered/incipiently weathered granites, which means that no significant element loss occurs in the granitic rocks suffering incipient weathering. Values from 70 to 75 indicate weathered granites (Table S3 in the supplementary material). In the ternary diagram, granite samples are grouped around 60-65 $\mathrm{Al}_{2} \mathrm{O}_{3} \%, 30-35 \mathrm{~K}_{2} \mathrm{O} \%$ and $20-25 \% \mathrm{CaO}+\mathrm{Na}_{2} \mathrm{O} \%$ (Fig. 4). Two trends of weathering occur, the first one correlated with $\mathrm{CaO}+\mathrm{Na}_{2} \mathrm{O}$ leaching (trend $\mathrm{A}$ ) and the second with $\mathrm{K}_{2} \mathrm{O}$ leaching (trend B) essentially attributed to biotite and feldspar alteration. The granites mostly affected by trend $B$ have the highest CIA values, 73 to 76 (Table S3 in the supplementary material), referring to a probable supergene contribution to the alteration state.

Lamprophyres: the CIA value of the lower part of the lamprophyre dyke is 61, similar to a typical granite value. Highly weathered surficial lamprophyre dyke samples follow the "intense weathering" trend $\mathrm{B}$ towards an $\mathrm{Al}_{2} \mathrm{O}_{3} /$ kaolinite enrichment. $\mathrm{CIA}$ values for the surficial lamprophyre samples range from 68 to 77.

Hydrothermally altered samples: most CIA values for sulfide-rich samples are similar to the mean granitic values, ranging from 57 to 65 . The three calcite-rich hydrothermally altered granites show low CIA values (from 36 to 49) (Table S3 in the supplementary material). However, these CIA values are biased due to their high content of CaO (13 to 16\%). CIA values of the calcite-rich and of the sulfide-rich samples are shifted towards the $\mathrm{CaO}$ apex or the $\mathrm{K}_{2} \mathrm{O}$ apex respectively on the ternary diagram. Both groups follow the same trends of weathering ( $A$ and $B$ ) with an offset related to their mineral paragenesis. Within the calcite-rich group, the arrow on Fig. 4 points toward the sample with kaolinite with an important loss of $\mathrm{CaO}$ and $\mathrm{Na}_{2} \mathrm{O}$ (Table $\mathrm{S} 3$ in the supplementary material) suggesting an intense leaching.

Weathering products: CIA values of protosoils and technosoils (62-64) highlight incipient weathering in the coarse groundmass and immature technosoils. The humic fraction is extremely limited, correlated with L.O.I values between 2 and 4 \%. More mature technosoils have CIA values between 71 and 73 correlated with higher L.O.I 
values between 12 and $16 \%$ (Table S3 in the supplementary material). This could be explained by mature overburden with higher OM content.

Regardless of the type of samples, the composition of the clay fraction is shifted towards $\mathrm{Al}_{2} \mathrm{O}_{3}$ when compared to the bulk samples, following trend $\mathrm{A}$ and/or trend $\mathrm{B}$ on Fig. 4. CIA leads to an overestimation of the alteration state if the samples were affected by hydrothermal alteration (Scarciglia et al. 2016). On the contrary, CIA values are underestimated in the calcite-rich (and to a lesser extent the sulfide-rich) samples. But as a whole, the use of CIA on the great variety of samples combined with the $\left[\mathrm{Al}_{2} \mathrm{O}_{3}-\mathrm{K}_{2} \mathrm{O}-\left(\mathrm{CaO}+\mathrm{Na}_{2} \mathrm{O}\right)\right]$ diagram demonstrates coherent weathering trends from granitic blocks to technosoil samples despite their chaotic setting in the waste rock piles.

\subsection{Uranium speciation}

\subsubsection{Uranium minerals}

Uranium bearing minerals were investigated with optical microscopy and SEM-EDS in the different groups of samples. Neither ore minerals nor other $U$ bearing minerals may be identified by X-ray diffraction because of their minor occurrence in the rocks. However, microscopic investigations of the four groups of samples show the presence of accessory primary minerals, monazite and zircon (bearing up to $1 \%$ of U), with secondary U(VI)-minerals:

1- From the surface to the core, granitic rocks are affected by incipient weathering. Some isolated micrometric rosettes of U-oxyhydroxides (BEL-08-07, 315 ppm U) grow on smectite laths (Fig. 5a). These tabular-shaped U-oxyhydroxides are identified as schoepite $\left(\left(\mathrm{UO}_{2}\right)_{8} \mathrm{O}_{2}(\mathrm{OH})_{12} \cdot 12\left(\mathrm{H}_{2} \mathrm{O}\right)\right) .20$ to $40 \mu \mathrm{m}$ lamellar autunites $\left(\mathrm{Ca}\left(\mathrm{UO}_{2}\right)_{2}\left(\mathrm{PO}_{4}\right)_{2} \cdot 10-12 \mathrm{H}_{2} \mathrm{O}\right)$ precipitates on flat apatite surface (MAC-08-01, $100 \mathrm{ppm}$ U) (Fig. 5b). In addition, apatite shows dissolution figures.

2- In the deep lamprophyre dyke (BEL-05-15, 15 ppm U), occasional fluorite and apatite, known to occur as primary phases in these rocks (Rock 1984), were observed but no secondary $U$ bearing mineral was spotted. By contrast, the highly weathered surficial lamprophyre dyke (BEL-05-08 to BEL-05-10, 221 to 493 ppm U) concentrates U. 
The only secondary $U$ bearing mineral present is autunite as large layered crystals (Fig. 5f) presenting characteristic tabular sheets that grow in a clayey matrix.

3- In the sulfide-rich yellowish granite (FAN-01-01, 348 ppm U), sub-micrometric needles of uranyl sulfate minerals, associated to Th rich nanoparticles (Appendix Cd), crystallize within a jarosite and smectite assemblage (Fig. 5d). These rocks are partially covered by a $1 \mathrm{~mm}$ hard thick greyish crust. This crust is composed of a tubular La-Ce uranyl phosphate mat with smectite sheets and lichen (Fig. 5c). In the altered granite FAN-02-C1C, with a higher U concentration (997 ppm U), secondary uranyl phosphates associated to Fe-oxides precipitate as small, ill shaped phases in quartz fissures (Fig. 6). Nanometric uraninites are trapped in large (> $100 \mu \mathrm{m}$ ) pyrite crystals with etched surface shown by dissolution features (Appendix C-e). Bordering the pyrite crystal (Appendix C-f), secondary micrometric, ill shaped Fe sulfates and uranyl phosphates fill a fissure, suggesting oxidizing conditions destabilizing the pyrite, confirmed by local $\mathrm{Fe}$ and S concentrations. In the calcite-rich hydrothermally altered granites (PEN-08-1 1, 1500 ppm U), stellate needle aggregates of uranophane $\left(\mathrm{Ca}\left(\mathrm{UO}_{2}\right)_{2} \mathrm{Si}_{2} \mathrm{O}_{7} \cdot 6 \mathrm{H}_{2} \mathrm{O}\right)$ cover the pitted surface of large calcite crystals, pointing out a dissolution process (Fig. 5e). U rich coatings, several ten $\mu \mathrm{m}$ large, are observed on quartz confirming $U$ mobility in these samples (Appendix C-c).

4- Among the weathering products, secondary $U$ minerals are rare in the arena. Patches of sub-micrometric platy curite $\left(\mathrm{Pb}_{3}\left(\mathrm{UO}_{2}\right)_{8} \mathrm{O}_{8}(\mathrm{OH})_{6} \cdot 3\left(\mathrm{H}_{2} \mathrm{O}\right)\right)$ are encrusted in a smectite matrix (BEL-08-09, 3000 ppm U) (Appendix C-a, and b). Protosoils (PEN-05-08, 38 ppm $U$ and PEN-05-11, 69 ppm $U$ ) reveal late jarosite rosettes growing on the surface of feldspars, quartz and various clay minerals (kaolinite, smectite and chlorite). Apart from primary accessory minerals, monazites and zircons, no $U$ bearing minerals were observed in protosoils.

\subsubsection{Uranium geochemistry}

Of the 54 samples analyzed, $74 \%$ have an $U$ content below the initial $U$ "cut-off value" (300 ppm), among which $22 \%$ have $U$ concentrations below the regional background value of 20 ppm (Table S3 in the supplementary material). Most granitic samples are affected by incipient weathering (CIA values of 60 to 65), except for the 
subgroup of intensely weathered granite (CIA 75) and the surficial lamprophyre samples, as discussed above. Because of their specificity humic horizon sample and ferrihydrite-rich samples are excluded from plots but will be discussed later. The bivariate plot $\mathrm{CIA} / \mathrm{U}$ indicates that weathering induces a reconcentration of $U$ into the clay fraction (Fig. 7). Two domains are highlighted: the $U$ geological background and the $U$ "cut-off range". The first with $U<20$ ppm, contains mainly granitic bulk rocks affected by incipient weathering and the subgroup with CIA values around 75, previously described as intensely weathered samples (§ 3.1.2). Only two granitic samples with low CIA values (around 60) have $U$ concentrations above the initial cut off value (> 300 ppm), with 314 and 1000 ppm for samples BEL-08-07 and PEN-01-06, respectively (Table $\mathrm{S} 3$ in the supplementary material). This exceptional $U$ concentration of 1000 ppm may be explained by the sorting between ore and waste rocks, based on large volumes (§ 2.1). The second domain concerns the weathering products, the weathered lamprophyres and the hydrothermally altered, sulfide-rich granites. $U$ enrichment is noticeable in the weathering products, increasing progressively from 30 up to 4000 ppm in the technosoils.

The highest $U$ concentrations in the clay fractions suggest local $U$ mobility and reconcentration in the finest granulometric fraction during arenization. The reconcentration of $U$ in the clay fraction varies from 28 to $85 \%$ (Table $S 4$ in supplementary material). A similar trend for rocks affected by previous hydrothermalism is noticeable with an offset at the origin related to their higher bulk rock $U$ concentration.

Phosphate minerals and Fe-oxides are common U(VI) sinks. Samples with about $1 \%$ $\mathrm{Fe}_{2} \mathrm{O}_{3}$ present $U$ concentrations ranging from 2 to 50 ppm. When $\mathrm{Fe}_{2} \mathrm{O}_{3}$ content reaches about $2 \%$, a higher ( $\times 10) \cup$ concentration (100 to $1000 \mathrm{ppm}$ ) is observed in granites and hydrothermally altered samples (Fig. 8). This $U$ enrichment is especially visible in most technosoils with U values within, or above, the "initial cut-off range".

The most common $U$ bearing minerals are monazite and various secondary uranyl phosphates described above. Fig. 9 represents a $\mathrm{P}_{2} \mathrm{O}_{5}-\mathrm{U}$ bivariate plot. In incipient weathered granites and weathering products, $\mathrm{P}_{2} \mathrm{O}_{5}$ is between 0.3 and $0.4 \%$. These values can be attributed to primary and/or secondary minerals. The low $\mathrm{P}_{2} \mathrm{O}_{5}$ concentrations (< $0.3 \%$ ) in weathered granite, lamprophyres and calcite-rich hydrothermally altered granites are attributed to primary mineral leaching. The clay fractions in arena, technosoils and lamprophyres show a high enrichment in $\mathrm{P}_{2} \mathrm{O}_{5}, \mathrm{up}$ 
to $0.9 \%$, with the exception of the calcite-rich samples in which uranophane was observed, where it stays constant. Moreover the slope of increase of $U$ and $\mathrm{P}_{2} \mathrm{O}_{5}$ in the clay fraction compared to the bulk samples is always positive but varies widely between 0.7 and 8.2. Nevertheless, the highest $\mathrm{P}_{2} \mathrm{O}_{5}$ and $U$ values in the clay fraction suggest neoformation of secondary uranyl phosphates and/or mechanical weathering with concentration of heavy minerals.

The high $U$ concentrations might be explained by a mechanical concentration of primary accessory minerals. Petrological observations suggest that $\mathrm{Zr}$ and $\mathrm{Ce}$ concentrations can be used to assess the zircon and monazite content, respectively. Microprobe measurements have shown that these accessory minerals contain up to $1 \%$ of $\mathrm{UO}_{2}$. In the blocks and arena, $\mathrm{Zr}$ and $\mathrm{Ce}$ concentrations increase in clay fractions relative to bulk samples, with the exception of the protosoil sample in which $\mathrm{Ce}$ decreases in the clay fraction (Table $\$ 4$ in supplementary material). To assess the correlation between mechanical weathering and geochemical enrichment, granulometric separations were performed on 7 samples from the weathering products group (2 arenas and 5 technosoils) (Table S5 in supplementary material). Mineralogical and geochemical data for each fraction are compared for a representative technosoil (FAN-02-C2, 237 ppm U) (Fig. 10). The concentration of clay minerals (chlorite and kaolinite) increases from gravel to silt/clay fraction, while that of primary minerals (micas and feldspars) decreases (Fig. 10a). The U concentration in the silt/clay fraction increases by up to one order of magnitude, compared to the gravel fraction. Within this granulometric distribution, $U$ is well correlated to $\mathrm{Fe}_{2} \mathrm{O}_{3}$, $\mathrm{P}_{2} \mathrm{O}_{5}, \mathrm{Zr}$ and $\mathrm{Ce}$ and to the $\mathrm{ClA}$ (Fig. 10b to f). The best correlations observed are between $U$ and $\mathrm{ClA}\left(r^{2}=0.98 ; n=5\right), U$ and $\mathrm{Fe}_{2} \mathrm{O}_{3}\left(r^{2}=0.89 ; n=5\right)$ and $U$ and $\mathrm{P}_{2} \mathrm{O}_{5}\left(r^{2}=0.94\right.$; $\mathrm{n}=5$ ). Concerning primary accessory minerals, $U$ and $\mathrm{Zr}$ concentrations are well correlated ( $\left.r^{2}=0.80 ; n=5\right)$ (Fig. 10e) whereas $U$ vs. Ce gives a moderate correlation $\left(r^{2}=0.63 ; n=5\right)$ (Fig. 10c) implying $U$ is preferentially concentrated in zircons rather than monazites.

\section{Discussion}

4.1 Site characteristics and differences 
Sites stand out in geochemical trends only when a group was found in one particular location such as the hydrothermally altered granites with sulfides, only sampled on Fanay, the hydrothermally altered group with calcite only found on Pény, or the ferrihydrite pools only sampled on Hyverneresse. Therefore, separation of samples by group overrules the sampling site. In a time span as short as sixty years, no difference is observed between thirty-year or sixty-year-old sites.

\subsection{Identification of incipient weathering}

To determine the importance of weathering in a time span of sixty years, this study focused on the surficial part the piles. Field observations have been combined with geochemical, mineralogical and micromorphological analyses to identify the various alteration processes in the waste rock piles. Meteoric water circulation and vegetation penetration induced chemical alteration and mechanical constraints in most surficial granitic blocks (20 cm large on average). Arenization of the blocks is more efficient if the blocks are affected by previous alteration (hydrothermalism, supergene). On the arena, protosoils appear with the development of lichen or the growth of birch trees.

Weathering intensity, quantified by $\mathrm{ClA}$, is assumed to be incipient when $55<\mathrm{ClA}<$ 65 and intense when $\mathrm{CIA}>70$. Therefore, the 4 granitic samples, out of the 27 investigated, which have $\mathrm{ClA}>70$, were probably affected by a supergene alteration episode prior to the waste rock pile edification. Indeed, similar CIA values have been observed on natural regoliths in temperate climates (Nesbitt and Young 1989; Price and Velbel 2003; Scarciglia et al. 2016). As pointed out above, samples affected by previous hydrothermal episodes should be handled with care in such geochemical diagrams since hydrothermalism can modify CIA values (Scarciglia et al. 2016). Therefore, such geochemical classification must be complemented by a thorough mineralogical identification.

The trends ( $A$ and $B$, Fig. 4) are characteristic of a loss of $\mathrm{CaO}, \mathrm{Na}_{2} \mathrm{O}$ and/or $\mathrm{K}_{2} \mathrm{O}$ during weathering and thus, of an $\mathrm{Al}_{2} \mathrm{O}_{3}$ enrichment. This is concordant with an increasing concentration of secondary clay mineral. As a general conclusion, geochemistry data are consistent with the fact that the main weathering products are clay minerals (kaolinite, chlorite, smectite and interstratified clay minerals), phosphates and Fe-oxides. 
In order to assess the effect of long term weathering of these waste rock piles, lamprophyre outcrops were analyzed for mineralogical and geochemical signatures. The good fit of deep lamprophyre rock to incipient weathering pole and surficial lamprophyres to highly weathered samples, in the overall geochemical trends, indicates that using surficial lamprophyre as a weathering proxy could provide a model for assessing the waste rock behavior under long periods of weathering.

\subsection{Uranium bearing minerals}

No remnant of $U$ ore minerals (uraninite, coffinite, pitchblende) has been encountered in the waste rock-pile. Similarly, previous weathering studies on the Saint-Sylvestre two-mica granitic massif have shown the absence of uraninite in the first $50 \mathrm{~m}$ (Barbier and Ranchin 1969). The absence of uraninite in our samples, when samples contain more than $30 \mathrm{ppm}$ of $\mathrm{U}$, is an indicator of the oxidized state of the surficial waste rock pile under leaching conditions. When $U$ concentration is below 30 ppm samples might never have contained uraninite, this concentration being explained by the presence of zircon and monazite.

Because the secondary bearing minerals crystallize in the bulk of surficial rock it is unlikely that $U$ was transported by percolating water in the rock fractures. Therefore the absence of primary $U(I V)$ is most likely due to oxidation of primary $U(I V)$ minerals. Although we did not observe micron size uraninites trapped in quartz or feldspar, like in the deeper part of the piles (Boekhout et al. 2015), nanometric uraninites were found trapped in large pyrites suggesting relict reduced areas in the surficial pile (Appendix C-e). As pyrite dissolution would ensue in an oxidizing environment, uraninites would be dissolved, $U(I V)$ oxidized to $U(V I)$ and secondary $U$ minerals precipitated.

Monazites and zircons are the only $U$ bearing primary minerals present in all samples with a maximum $U$ concentration of $1 \%$. However, these minerals are resistant to weathering (Scherrer et al. 2000) and cannot be considered as a source of $U$ during incipient chemical weathering. Mechanical weathering concentrates zircons and monazites in the clay fraction, due to their small size $(1-20 \mu \mathrm{m})$. Considering the $U$ concentration in zircon and monazite and the $\mathrm{Zr}$ and Ce mean concentration in granites, these phases cannot account for more than 10 to $30 \mathrm{ppm} U$ in the bulk samples. 
Secondary $U$ bearing minerals crystallize in different environments controlled by recent processes and affected by geological history: in calcite-rich sample uranophane precipitates on a calcite surface. Calcite is known to be an efficient uranyl sorbent (Dong et al. 2005). Therefore precipitation of uranophane can be interpreted as a two steps mechanism of $U$ trapping by sorption and further precipitation of uranophane concordant to calcite dissolution. Uranyl silicate precipitation as coating on quartz (Appendix C-C) is also experimentally observed with $\mathrm{SiO}_{2}$ colloids and was shown to happen at slightly acidic pH (Lamb et al. 2016) comparable to the $\mathrm{pH}$ range of waste rock piles. In sulfide-rich samples, La-Ca-Th-U-P tubules in the external greyish alteration crust are comparable to florencite/rhabdophane precipitation after apatite weathering (Taunton et al. 2000). In the bulk of the sample uranyl sulfates co-precipitates with hydrated hexavalent $U$ or Th oxides is possibly related to weathering of the uraninite-thorianite solid solution series. In the arena sample, curite is mixed with clay minerals (Appendix C-a and b). Curite is known to enhance the formation of insoluble uranyl phosphates (Finch and Ewing 1992). Crystallization of various secondary $U$ minerals in the different groups of samples proves the $U$ trapping depends on the geological history of the sample. This has an impact on $U$ mobility. Uranyl phosphates, such as meta-autunite, are known in natural systems as $U$ sequestration products during weathering (Barbier and Ranchin 1969; Jerden and Sinha 2003; Jerden et al. 2003; Jerden and Sinha 2006; Abd El-Naby and Dawood 2008). In most granitic samples, lamellar autunites crystallize and form thin coatings on apatite (Fig. 5b). Their micromorphology and presence is typical of incipient weathering. The different morphology in the highly weathered lamprophyre (autunite layered crystals (Fig. 5f) with tabular sheets in the clayey matrix) suggests a more mature process of supergene alteration. Therefore, the autunites in most granite from the piles are formed from incipient weathering, whereas autunite growth in lamprophyre is formed over a long period of supergene alteration. The regular occurrence of uranyl phosphates in diverse samples from the surface of the piles confirms a process of $U$ sequestration in specific minerals. Given the $\mathrm{P}_{2} \mathrm{O}_{5}$ concentration in samples uranyl phosphates could be the main $U$ trapping process for U concentrations up to 4550 ppm (Table S3 in the supplementary material). Still, not all $\mathrm{P}_{2} \mathrm{O}_{5}$ is available for $U$ sequestration, a significant part belongs to apatite, monazite and other primary phosphates, and therefore other sequestration processes must also be considered. 


\subsection{Overall Uranium speciation in the waste rock piles}

Ferrihydrite pools and technosoil downslopes concentrate weathering products. No secondary $U$ minerals were identified in ferrihydrite samples. Nevertheless, the high U concentration (2500 ppm) combined with the significant amount of $\mathrm{P}_{2} \mathrm{O}_{5}(2.5 \%$, i.e. five to ten times more than in other samples from the waste rock piles), suggests an intricate process in $U$ sequestration. Ferrihydrite is known to have an important role in U sequestration by sorption processes (Waite et al. 1994; Reich et al. 1998). The role of phosphate in enhancing $U$ adsorption on ferrihydrite was evidenced and attributed to the formation of ternary complexes involving $\mathrm{UO}_{2}{ }^{2+}$ and $\mathrm{PO}_{4}{ }^{3-}$ (Payne et al. 1996). In the ferrihydrite samples of the pools the slightly acidic $\mathrm{pH}$ favors these ternary complexes. Trapping of important amounts of $U$ by ferrihydrite suggests either chemical migration of $U$ towards downslope weathering products, or mechanical migration of micrometric secondary uranyl phosphates and chemical reactivity in the ferrihydrite pool.

More mature technosoils bear the highest $U$ concentration; with eventually an L.O.I value of $48.5 \%$ which indicates a high organic matter content, highlighting the important influence of organic matter in U sequestration (Cumberland et al. 2016). U sequestration by OM should be considered as a long term sink with development of vegetation on waste rock piles. Nevertheless in most samples of the piles, $\mathrm{OM}$ is negligible and other $U$ sinks may be responsible for $U$ sequestration.

In clay fractions, $U$ enrichment is observed in lamprophyres with interstratified clay minerals and in granitic arenization matrix and protosoils with smectite. $U$ could be sequestrated by clay minerals (Tsunashima et al. 1981; Chisholm-Brause et al. 1994; Schlegel and Descostes 2009). The sorption efficiency of smectite favors the nucleation of uranyl minerals (Schindler et al. 2015), limiting $U$ migration in the pile. Clay minerals are known as an efficient $U$ sequestration system, they are generally used as a liner to limit environmental impact of metallic pollutants (Rowe et al. 2004). Fe-oxides and clay minerals play an important role in radionuclide migration, efficiently trapping uranyl as inner- and/or outer-sphere complexes at their surface (Brown and Calas 2012; Neiva et al. 2014; Cabral-Pinto et al., 2014).

Granulometric separations have shown a good correlation of clay minerals, $\mathrm{P}_{2} \mathrm{O}_{5}$ and Fe-oxides to $U$ concentration. The sorption efficiency of the major phases (clay 
minerals, Fe-oxides) is probably the dominant process of $U$ sequestration; however, the presence of nanometric $U$ bearing minerals embedded in these divided secondary phases should not exclude the possible role of phosphates in efficient sequestration.

\section{Conclusion}

No trace of relict uranium ore was found in the investigated samples. The scarcity of uraninite trapped in pyrite confirms the global oxidation state of the surficial waste rock pile. The weathering degree of each sample, in the chaotic deposits of waste rock piles, was successfully assessed relying on the $\mathrm{ClA}$ value (around 60 for incipient weathering, and 70 for intense weathering), the mineralogy and the micromorphological observations. Hexavalent uranium is known for its high mobility, hence its early migration within the waste rock pile since the beginning of the incipient weathering. It is concentrated in the finest fraction, the $U$ content being controlled by the low solubility of neoformed uranyl minerals, mainly uranyl phosphates, the cationic exchange capacity of smectites and the sorption efficiency of ferrihydrite. The evolution of oxidation in depth of the waste rock pile and the associated weathering processes were investigated in a preliminary study (Boekhout et al. 2015), showing overall oxidation of the waste rock pile with dominantly uranyl phosphate precipitation. Secondary uranyl phosphates are important in the presently investigated surficial samples, as they are the dominant secondary $U$ mineral found and are known to cause low levels of aqueous uranium in groundwaters due to their low solubility (Munasinghe et al. 2015). The different micromorphology of autunites, from well-defined layered crystal in lamprophyres compared to isolated lamellae in granites, has been related to the duration of weathering. Other secondary uranyl minerals also ensure $U$ trapping, such as uranophane and uranyl sulfates. The present investigation shows that large amounts of Fe oxyhydroxides concentrate downslope of the waste rock piles. This important result confirms the primary role of Fe-oxyhydroxides in limiting $U$ mobility under slightly acidic $\mathrm{pH}$ domains and oxidizing environments. Based on the influence of surficial incipient weathering of the waste rock piles, a realistic assessment of the environmental evolution will imply investigating deep weathering processes, under different redox conditions. 


\section{Acknowledgements}

This research was supported by AREVA Mines R\&D. The purchase of the Scanning Electron Microscope (SEM) facility of the Institut de Minéralogie, de Physique des Matériaux et de Cosmochimie (IMPMC) was supported by Région lle de France grant SESAME 2006 NoI-07-593/R, INSU-CNRS, INP-CNRS, University Pierre et Marie Curie - Paris 6 and by the French National Research Agency (ANR) grant $n^{\circ}$ ANR-07-BLAN0124-01. We thank T. Poquet (AREVA), E. Bonhoure (SET Environnement), A. Michel (IPGP), T. Pilorge, S. Caquineau, F. LeCornec, I. Djouarev (IRD), I. Estève, O. Boudouma, M. Fialin, F. Couffignal, J. Brest, S. Locati, L. Delbes (UPMC) and A.E. Sergienko for their precious technical assistance and/or advice. We would also like to thank Kevin Ansdell, an anonymous reviewer and Associate Editor Karel Breiter for their thorough revisions, suggestions and comments, which strongly improved our manuscript.

\section{References}

Abd El-Naby, H.H., and Y.H. Dawood. 2008. "Natural Attenuation of Uranium and Formation of Autunite at the Expense of Apatite within an Oxidizing Environment, South Eastern Desert of Egypt." Applied Geochemistry 23: 3741-55.

Allard, T., P. Ildefonse, C. Beaucaire, and G. Calas. 1999. "Structural Chemistry of Uranium Associated with Si, Al, Fe Gels in a Granitic Uranium Mine." Chemical Geology, 158: 81-103.

AREVA. 2004. "Bilan Décennal Environnemental 1994-2003." Etablissement de Bessines.

Barbier, J., and G. Ranchin. 1969. "Influence de l'altération météorique sur l'uranium à l'état de traces dans le granite à deux micas de St-Sylvestre." Geochimica et Cosmochimica Acta 33: 39-47.

Boekhout, F., M. Gérard, A. Kanzari, A. Michel, A. Déjeant, L. Galoisy, G. Calas, and M. Descostes. 2015. "Uranium Migration and Retention during Weathering of a Granitic Waste Rock Pile." Applied Geochemistry 58: 123-35.

Braga, S., H. Paquet, and A. Begonha. 2002. "Weathering of Granites in a Temperate Climate (NW Portugal): Granitic Saprolites and Arenization." Catena 49: 41-56.

Brown, G.E., and G. Calas. 2012. "Mineral-Aqueous Solution Interfaces and Their Impact on the Environment." Geochemical Perspectives 1: 483-484.

Cabral Pinto, M.M.S., M.M.V.G. Silva, and A.M.R. Neiva. 2014. "Release, Migration, Sorption and (Re)precipitation of $U$ During a Granite Alteration under Oxidizing Conditions." Procedia Earth and Planetary Science 8: 28-32.

Cathelineau, M. 1983. "Potassic Alteration in French Hydrothermal Uranium Deposits." Mineralium Deposita 18: 89-97. 
Chisholm-Brause, C., S.D. Conradson, C.T. Buscher, P.G. Eller, and D.E. Morris. 1994. "Speciation of Uranyl Sorbed at Multiple Binding Sites on Montmorillonite." Geochimica et Cosmochimica Acta 58: 3625-31.

Cumberland, S.A., G. Douglas, K. Grice, and J.W. Moreau. 2016. "Uranium Mobility in Organic Matter-Rich Sediments: A Review of Geological and Geochemical Processes." Earth-Science Reviews 159: 160-85.

Cuney, M. 2014. "Felsic Magmatism and Uranium Deposits." Bulletin de La Societe Geologique de France 185: 75-92.

Dahlkamp, F.J. 1993. "Principal Aspects of the Genesis of Uranium Deposits." In Uranium Ore Deposits, 41-56. Springer.

Finch, R.J., and R.C. Ewing. 1992. "The Corrosion of Uraninite under Oxidizing Conditions." Journal of Nuclear Materials 190: 133-56.

Gilkes, R.J., G. Scholz, and G.M. Dimmock. 1973. "Lateritic Deep Weathering of Granite." Journal of Soil Science 24: 523-536.

Guillén, J., J.J. Tejado, A. Baeza, A. Salas, and J.G. Muñoz-Muñoz. 2014. "Environmental Impact of a Granite Processing Factory as Source of Naturally Occurring Radionuclides." Applied Geochemistry 47: 122-29.

Guthrie, V.A., and J.D. Kleeman. 1986. "Changing uranium distributions during weathering of granite." Chemical geology 54: 113-126.

lelsch, G., M. Cuney, F. Buscail, F. Rossi, A. Leon, and M.E. Cushing. 2016. "Estimation and Mapping of Uranium Content of Geological Units in France." Journal of Environmental Radioactivity. In press corrected proof. http://dx.doi.org/10.1016/j.jenvrad.2016.05.022

International Atomic Energy Agency. 2009. World Distribution of Uranium Deposits (UDEPO) with Uranium Deposit Classification. Vienna, Austria: International Atomic Energy Agency.

IRSN. 2007. "Expertise globale du bilan décennal environnemental d'AREVA N. C." DEI/SARG/2007-042. Institut de Radioprotection et de Sûreté Nucléaire. http://www.iaea.org/inis/collection/NCLCollectionStore/_Public/40/109/40109441.pd f.

Jamieson, H.E., S.R. Walker, and M.B. Parsons. 2015. "Mineralogical Characterization of Mine Waste." Applied Geochemistry 57: 85-105.

Jerden, J.L., and A.K. Sinha. 2006. "Geochemical Coupling of Uranium and Phosphorous in Soils Overlying an Unmined Uranium Deposit: Coles Hill, Virginia." Journal of Geochemical Exploration 91: 56-70.

Jerden, J.L., A.K. Sinha, and L. Zelazny. 2003. "Natural Immobilization of Uranium by Phosphate Mineralization in an Oxidizing Saprolite-soil Profile: Chemical Weathering of the Coles Hill Uranium Deposit, Virginia." Chemical Geology 199: 12957.

Jerden Jr, J.L., and A.K. Sinha. 2003. "Phosphate Based Immobilization of Uranium in an Oxidizing Bedrock Aquifer." Applied Geochemistry 18: 823-843.

Jin, Q., L. Su, G. Montavon, Y. Sun, Z. Chen, Z. Guo, and W. Wu. 2016. "Surface Complexation Modeling of $\mathrm{U}(\mathrm{VI})$ Adsorption on Granite at ambient/elevated Temperature: Experimental and XPS Study." Chemical Geology 433: 81-91.

Kelly, S.D. 2010. "Uranium Chemistry in Soils and Sediments." Developments in Soil Science 34: 411-466.

Kipp, G.G., J.J. Stone, and L.D. Stetler. 2009. "Arsenic and Uranium Transport in Sediments near Abandoned Uranium Mines in Harding County, South Dakota." Applied Geochemistry 24: 2246-55. 
Knox, A.S., D.I. Kaplan, and M.H. Paller. 2006. "Phosphate Sources and Their Suitability for Remediation of Contaminated Soils." Science of The Total Environment 357: 271-79.

Lamb, A.C.M., F. Grieser, and T.W. Healy. 2016. "The Adsorption of Uranium (VI) onto Colloidal TiO2, SiO2 and Carbon Black." Colloids and Surfaces A: Physicochemical and Engineering Aspects 499: 156-62.

Lechler, P.J., and M.O. Desilets. 1987. "A Review of the Use of Loss on Ignition as a Measurement of Total Volatiles in Whole-Rock Analysis." Chemical Geology 63: $341-44$.

Lee, J., M. Baik, J. Choi, and M. Seo. 2011. "Development of a Web-Based Sorption Database (KAERI-SDB) and Application to the Safety Assessment of a Radioactive Waste Disposal." Nuclear Engineering and Design 241: 5316-24.

Leermakers, M., V. Phrommavanh, J. Drozdzak, Y. Gao, J. Nos, and M.I Descostes. 2016. "DGT as a Useful Monitoring Tool for Radionuclides and Trace Metals in Environments Impacted by Uranium Mining: Case Study of the Sagnes Wetland in France." Chemosphere 155: 142-151.

Leroy, J. 1978. "The Margnac and Fanay Uranium Deposits of the La Crouzille District (Western Massif Central, France): Geologic and Fluid Inclusion Studies." Economic Geology 73: 1611-34.

-. 1984. "Episyénitisation Dans Le Gisement D'uranium Du Bernardan (Marche): Comparaison Avec Des Gisements Similaires Du Nord-Ouest Du Massif Central Français." Mineralium Deposita 19: 26-35.

Lespinasse, M., and M. Cathelineau. 1990. "Fluid Percolations in a Fault Zone: A Study of Fluid Inclusion Planes in the St Sylvestre Granite, Northwest Massif Central, France." Tectonophysics 184: 173-187.

Ménager, M., C. Menet, J. Petit, M. Cathelineau, and B. Côme. 1992. "Dispersion of U, Th, and REE by Water-Rock Interaction around an Intragranitic UVein, Jalerys Mine, Morvan, France." Applied Geochemistry 7: 239-252.

McLemore, V.T., K.M. Donahue, E. Phillips, N. Dunbar, P. Walsh, L.A.F. Gutierrez, S. Tachie-Menson, Shannon, H.R., Lueth, V. W., Campbell, A. R., Wilson, G. W., and Walker, B. M. 2006. "Characterization of Goathill North Mine Rock Pile, Questa Molybdenum Mine, Questa, New Mexico." International Conference of Acid Rock Drainage (ICARD). ASMR, St. Lovis. http://www.imwa.de/docs/imwa_2006/1219McLemore-NM.pdf.

Morin, G., A. Mangeret, G. Othmane, L. Stetten, M. Seder-Colomina, J. Brest, G. Ona-Nguema, Bassot, S., Courbet, C., Guillevic, J., Thouvenot, A., Mathon, O., Proux, O., Bargar, J.R. 2016. "Mononuclear U(IV) Complexes and Ningyoite as Major Uranium Species in Lake Sediments." Geochemical Perspectives Letters 2: 95-105.

Morris, D.E., P.G. Allen, J.M. Berg, C.J. Chisholm-Brause, S.D. Conradson, R.J. Donohoe, N.J. Hess, J.A. Musgrave, and C.D. Tait. 1996. "Speciation of Uranium in Fernald Soils by Molecular Spectroscopic Methods: Characterization of Untreated Soils." Environmental Science \& Technology 30 (7): 2322-2331.

Munasinghe, P.S., M.E. Elwood Madden, S.C. Brooks, and A.S. Elwood Madden. 2015. "Dynamic Interplay between Uranyl Phosphate Precipitation, Sorption, and Phase Evolution." Applied Geochemistry 58: 147-60.

Neiva, A.M.R., I.M.H.R. Antunes, P.C.S. Carvalho, and A.C.T. Santos. 2016. "Uranium and Arsenic Contamination in the Former Mondego Sul Uranium Mine Area, Central Portugal." Journal of Geochemical Exploration 162: 1-15

Neiva, A.M.R., P.C.S. Carvalho, I.M.H.R. Antunes, M.M.V.G. Silva, A.C.T. Santos, M.M.S. Cabral Pinto, and P.P. Cunha. 2014. "Contaminated Water, Stream Sediments 
and Soils close to the Abandoned Pinhal Do Souto Uranium Mine, Central Portugal." Journal of Geochemical Exploration 136: 102-17.

Nesbitt, H.W., and G.M. Young. 1989. "Formation and Diagenesis of Weathering Profiles." The Journal of Geology, 129-147.

Parbhakar-Fox, A.K., M. Edraki, K. Hardie, O. Kadletz, and T. Hall. 2014. "Identification of Acid Rock Drainage Sources through Mesotextural Classification at Abandoned Mines of Croydon, Australia: Implications for the Rehabilitation of Waste Rock Repositories." Journal of Geochemical Exploration 137: 11-28.

Payne, T.E., J.A. Davis, and T.D. Waite. 1996. "Uranium Adsorption on Ferrihydrite-Effects of Phosphate and Humic Acid." Radiochimca Acta 74 (S1): 23944.

Price, J.R., and M.A. Velbel. 2003. "Chemical Weathering Indices Applied to Weathering Profiles Developed on Heterogeneous Felsic Metamorphic Parent Rocks." Chemical Geology 202: 397-416.

Regenspurg, S., C. Margot-Roquier, M. Harfouche, P. Froidevaux, P. Steinmann, P. Junier, and R. Bernier-Latmani. 2010. "Speciation of NaturallyAccumulated Uranium in an Organic-Rich Soil of an Alpine Region (Switzerland)." Geochimica et Cosmochimica Acta 74: 2082-98.

Reich, T., H. Moll, T. Arnold, M.A. Denecke, C. Hennig, G. Geipel, G. Bernhard, H. Nitsche, P.G. Allen, and J.J. Bucher. 1998. "An EXAFS Study of Uranium (VI) Sorption onto Silica Gel and Ferrihydrite." Journal of Electron Spectroscopy and Related Phenomena 96: 237-243.

Rock, N.M.S. 1984. "Nature and Origin of Calc-Alkaline Lamprophyres: Minettes, Vogesites, Kersantites and Spessartites." Transactions of the Royal Society of Edinburgh: Earth Sciences 74: 193-227.

Rollinson, H.R. 2014. Using Geochemical Data: Evaluation, Presentation, Interpretation. Routledge.

Rowe, R.K., R.M. Quigley, R.W.I. Brachman, J.R. Booker, and R. Brachman. 2004. Barrier Systems for Waste Disposal Facilities. Spon Press.

Salama, W., I. González-Álvarez, and R.R. Anand. 2016. "Significance of Weathering and Regolith/landscape Evolution for Mineral Exploration in the NE Albany-Fraser Orogen, Western Australia." Ore Geology Reviews 73: 500-521.

Scaillet, S., A. Cheilletz, M. Cuney, E. Farrar, and D.A. Archibald. 1996. "Cooling Pattern and Mineralization History of the Saint Sylvestre and Western Marche Leucogranite Pluton, French Massif Central: I. 40Ar/39Ar isotopic Constraints." Geochimica et Cosmochimica Acta 60 (23): 4653-71.

Scarciglia, F., S. Critelli, L. Borrelli, S. Coniglio, F. Muto, and F. Perri. 2016. "Weathering Profiles in Granitoid Rocks of the Sila Massif Uplands, Calabria, Southern Italy: New Insights into Their Formation Processes and Rates." Sedimentary Geology 336: 46-67.

Scherrer, N.C., M. Engi, E. Gnos, V. Jakob, and A. Lietchi. 2000. "Monazite Analysis; from Sample Preparation to Microprobe Age Dating and REE Quantification" 80: 93-105.

Schindler, M.I., C.A. Legrand, and M.F. Hochella. 2015. "Alteration, Adsorption and Nucleation Processes on Clay-Water Interfaces: Mechanisms for the Retention of Uranium by Altered Clay Surfaces on the Nanometer Scale." Geochimica et Cosmochimica Acta 153: 15-36.

Schlegel, M.L., and M. Descostes. 2009. "Uranium Uptake by Hectorite and Montmorillonite: A Solution Chemistry and Polarized EXAFS Study." Environmental Science \& Technology 43: 8593-8598. 
Smith, L.J.D., B.L. Bailey, D.W. Blowes, J.L. Jambor, L. Smith, and D.C. Sego. 2013. "The Diavik Waste Rock Project: Initial Geochemical Response from a Low Sulfide Waste Rock Pile." Applied Geochemistry 36: 210-21.

Taboada, T., A. Martinezcortizas, C. Garcia, and E. Garciarodeja. 2006. "Uranium and Thorium in Weathering and Pedogenetic Profiles Developed on Granitic Rocks from NW Spain." Science of The Total Environment 356: 192-206.

Takaya, Y. 2014. "Which Constituent Mineral Is Dominant in Granite Weathering? A Solution-Sided Approach through a Laboratory Experiment." Geoderma 230-231: 204-11.

Taunton, A.E., S.A. Welch, and J.F. Banfield. 2000. "Microbial Controls on Phosphate and Lanthanide Distributions during Granite Weathering and Soil Formation." Chemical Geology 169: 371-382.

Tran, A.B., S. Miller, D.J. Williams, P. Fines, and G.W. Wilson. 2003. "Geochemical and Mineralogical Characterization of Two Contrasting Waste Rock dumps-The INAP Waste Rock Dump Characterization Project." In ICARD 2003Proceedings from the 5 Th International Conference on Acid Rock Drainage: The Australasian Institute of Mining and Metallurgy, Melbourne, 939-947. http://www.inap.com.au/public_downloads/Research_Projects/INAP_WRDC_Project .pdf.

Tsunashima, A., G.W. Brindley, and M. Bastovanov. 1981. "Adsorption of Uranium from Solutions by Montmorillonite; Compositions and Properties of Uranyl Montmorillonites." Clays and Clay Minerals 29: 10-16.

Waite, T.D., J.A. Davis, T.E. Payne, G.A. Waychunas, and N. Xu. 1994. "Uranium (VI) Adsorption to Ferrihydrite: Application of a Surface Complexation Model." Geochimica et Cosmochimica Acta 58: 5465-78.

Wang, Y., M. Frutschi, E. Suvorova, V. Phrommavanh, M. Descostes, A.A.A. Osman, G. Geipel, and R. Bernier-Latmani. 2013. "Mobile uranium(IV)-Bearing Colloids in a Mining-Impacted Wetland." Nature Communications 4: 2942.

White, A.F., and S.L. Brantley. 1995. "Chemical Weathering Rates of Silicate Minerals: An Overview." In Chemical Weathering Rates of Silicate Minerals, 31:1-22.

Wongfun, N., J. Götze, G. Furrer, H. Brandl, and M. Plötze. 2013. "Effect of Water Regime and Vegetation on Initial Granite Weathering in a Glacier Forefield: Evidences from CL, SEM, and Nomarski DIC Microscopy." Geoderma 211: 116-27. 


\section{FIGURES}
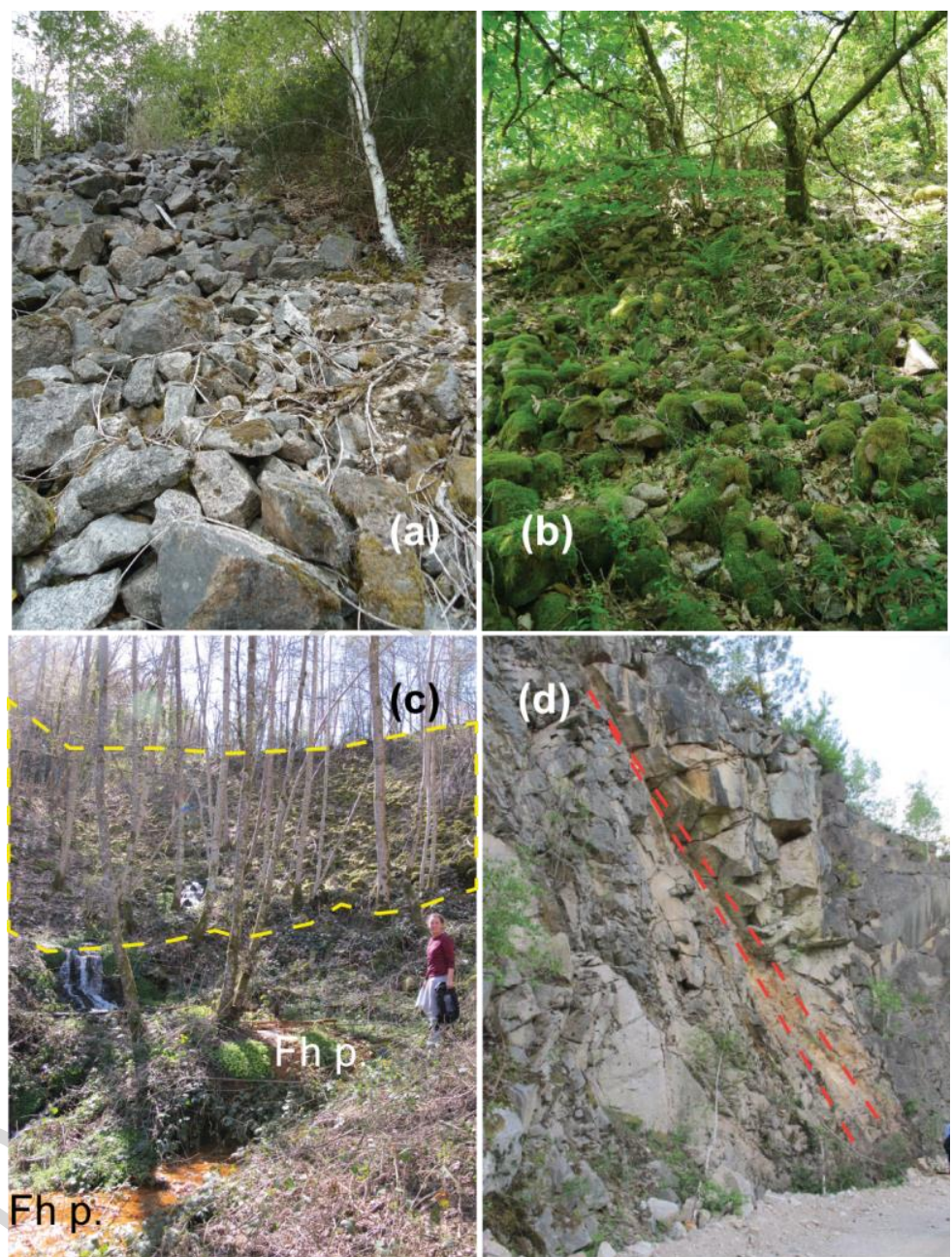

Fig. 1: Pictures showing the variety of samples collected. (a) Vegetalized granitic rock heap at Pény. (b) Well developed vegetation on Fanay's upper waste rock pile. (c) Ferrihydrite pools (Fh p.) downslope Hyverneresse waste rock pile. The waste rock pile (indicated by yellow dotted lines) shows vegetation development. (d) Lower lamprophyre dike at Bellezane. The dyke is indicated in the granitic massif by red dotted lines. 

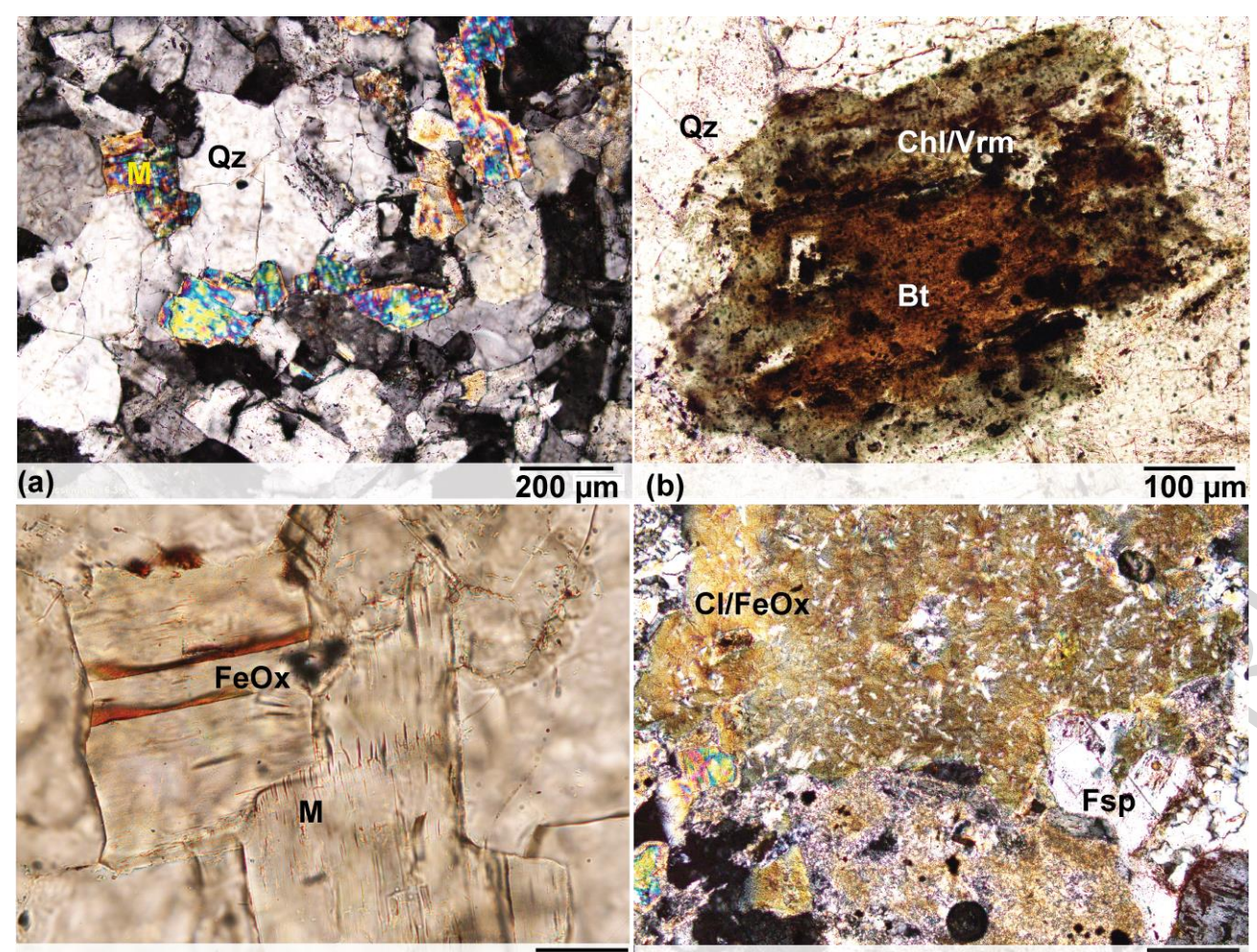

(c) $\overline{40 \mu \mathrm{m}}$ (d)

$200 \mu \mathrm{m}$

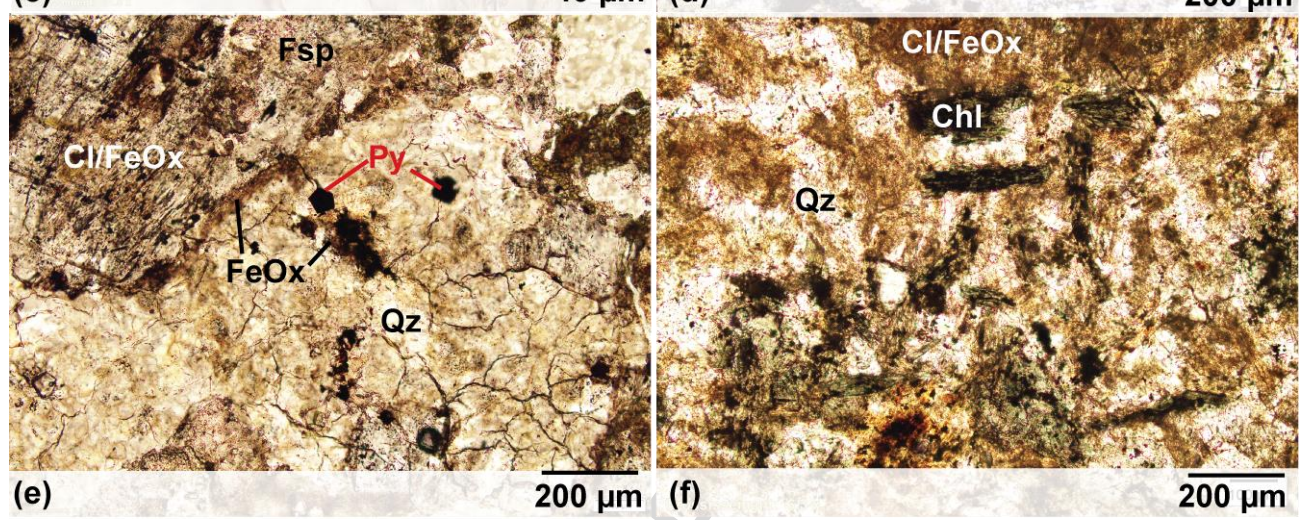

(e)

$200 \mu \mathrm{m}$ (f)

$200 \mu \mathrm{m}$

Fig. 2: Pictures under optical microscope. Abbreviations list: $\mathrm{Bt}=$ biotite, $\mathrm{Chl}=$ chlorite, $\mathrm{Vrm}=$ vermiculite $\mathrm{Cl}=$ clay minerals, $\mathrm{FeOx}=$ iron oxide, $\mathrm{Fsp}=$ feldspar, $M=$ mica, $P y=$ pyrite, $Q z=$ quartz, PPL: Plane polarized light, XPL: Cross polarized light.

a) Lesser altered granite from Margnac, XPL. Primary minerals: Qz, Fsp and M. b) Chlorite alteromorph after biotite in a granite from Bellezane, PPL. . Biotite shows radiation aureoles. c) Close up of (a), PPL: iron oxide veins in mica. d) Clay and iron oxide rich matrix in a granite from the sulfide-rich group from Fanay, XPL. e) Pyrite and iron oxides in a granite from the sulfiderich group from Fanay, PPL. $f$ ) Lamprophyre sample, from the lower part of the dyke, showing a clay and quartz rich matrix PPL. 


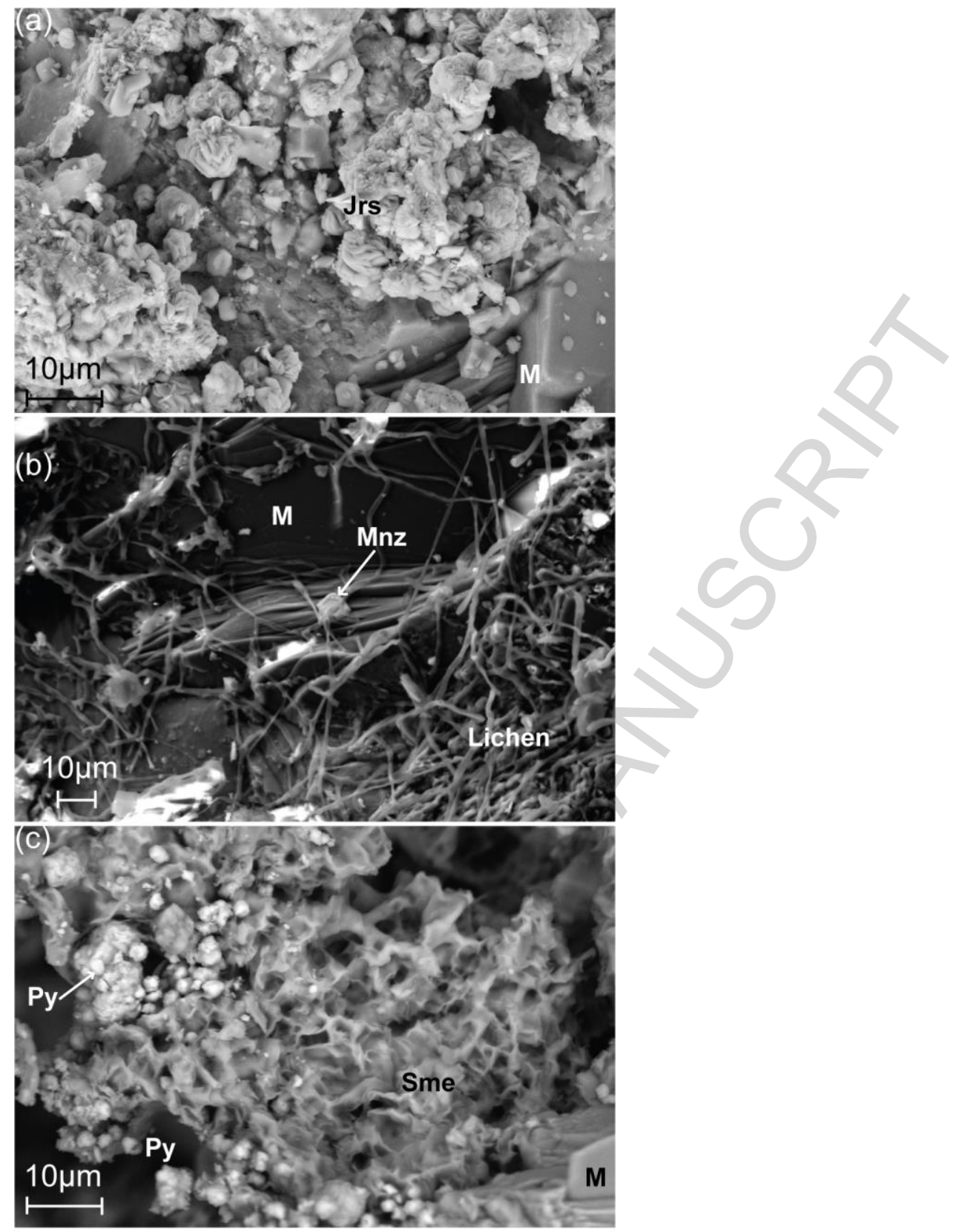

Fig. 3:SEM pictures of rock chips: (a) Backscattered electron image. Iron and potassium sulfate (Jarosite: Jrs) rosette formation on mica (M) and feldspar background in a sulfide-rich sample from Fanay. (b) Secondary electron image of lichen growth at the surface of micas. A monazite (Mnz) crystal is visible. (c) Secondary electron image of pyrites (Py) in smectite (Sme) and mica background in a sulfide-rich sample from Fanay. 


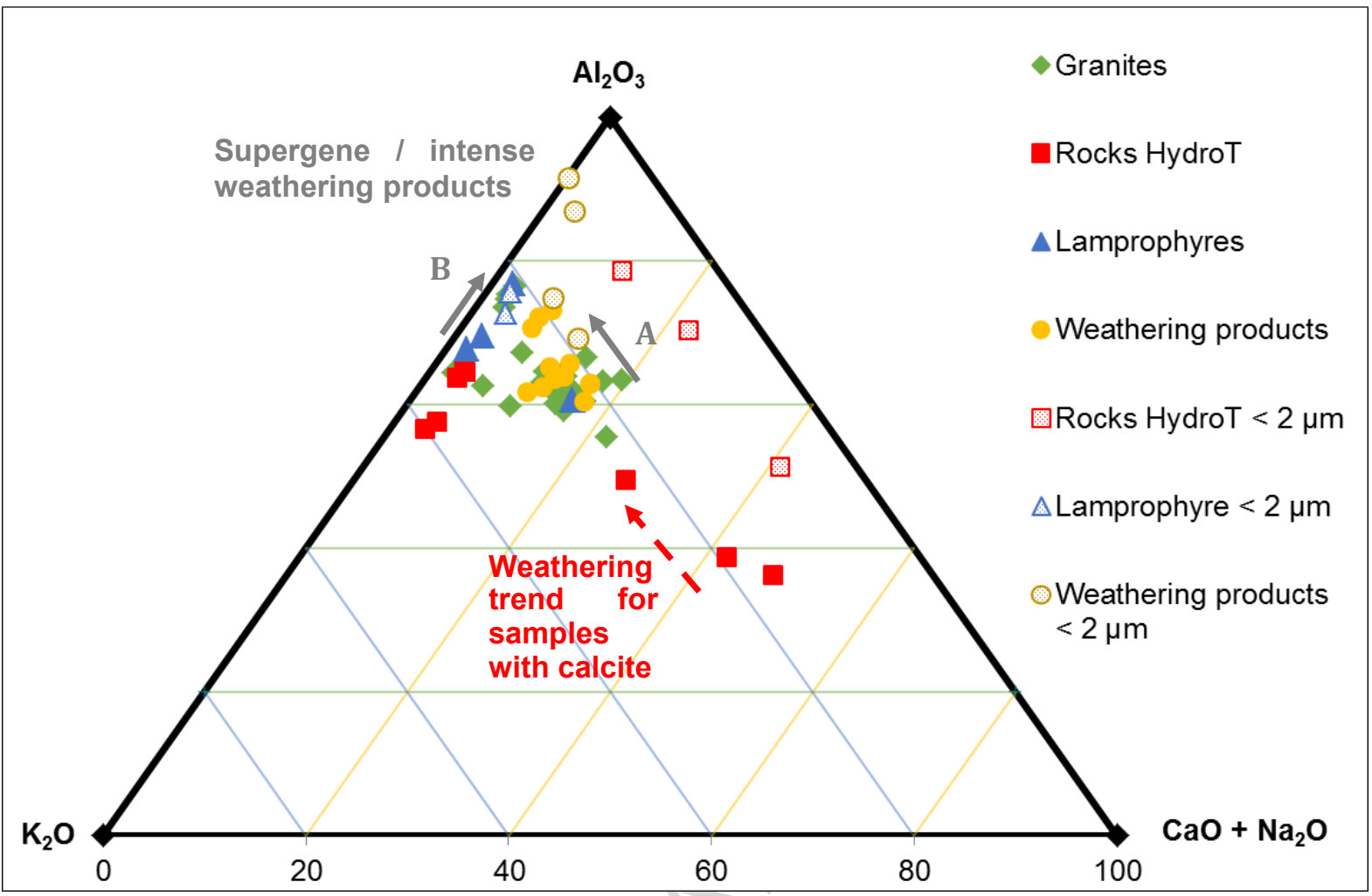

Fig. 4: Ternary $\mathrm{Al}_{2} \mathrm{O}_{3}-\mathrm{K}_{2} \mathrm{O}-\left(\mathrm{CaO}+\mathrm{Na}_{2} \mathrm{O}\right)$ diagram used as a proxy to the alteration state of samples. Trend $A$ goes from an incipient to an advanced weathering state. Trend $B$ goes from an advanced weathering state to an intense weathering state towards a theoretical kaolinite pole $\left(\mathrm{Al}_{2} \mathrm{O}_{3}\right)$. 

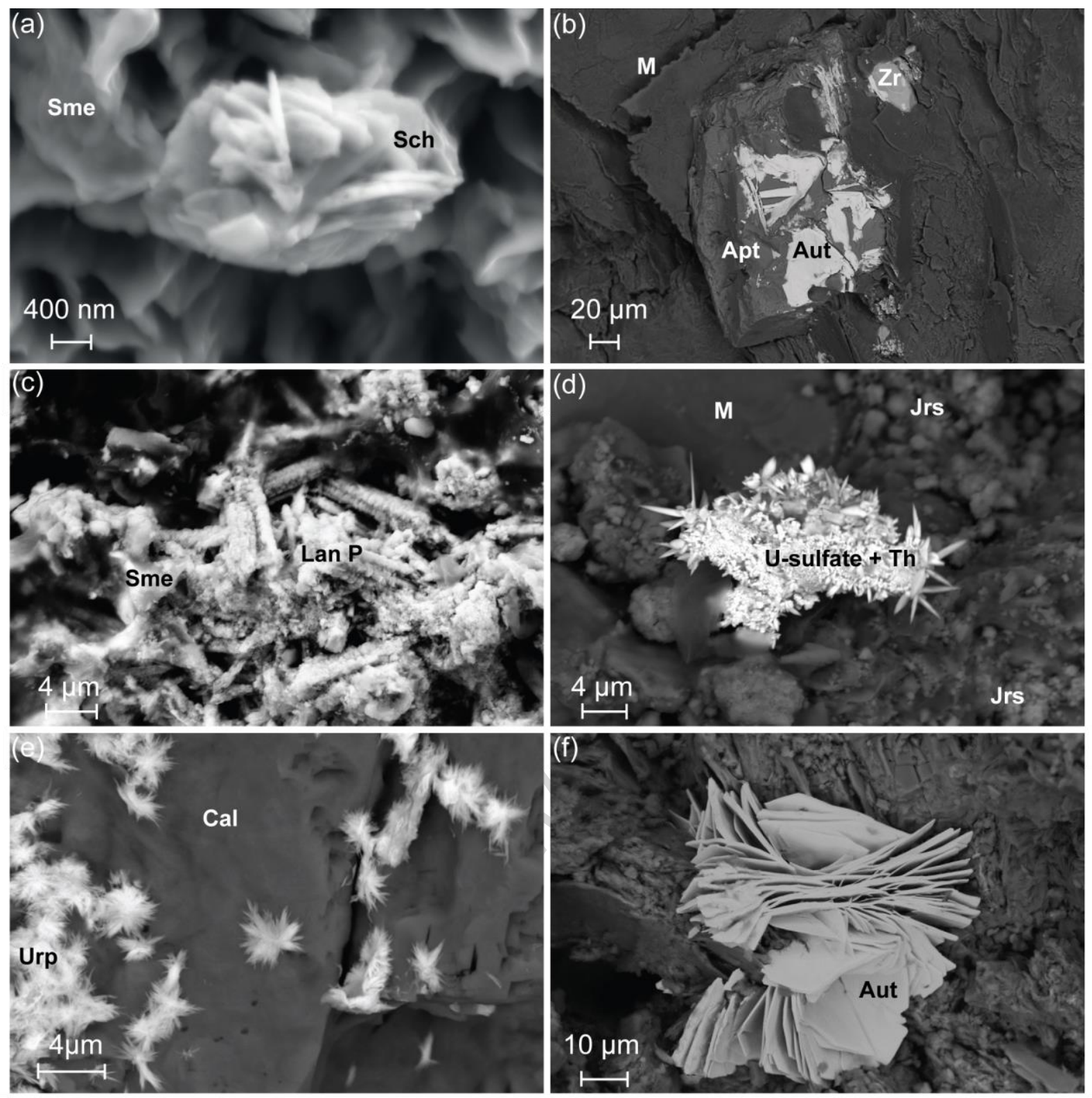

Fig. 5: SEM pictures of rock chips: (a) Secondary electron image. Nanometric rosettes of uranium oxyhydroxyde, schoepite (Sch), concentrated on a smectite ( $\mathrm{Sme}$ ) background, in granite (BEL-08-07). (b) Backscattered electron image of a granitic sample (MAC-08-01). Lamellar autunites (Aut) precipitate on apatite (Apt). Mica (M) and zircon (Zr) are present in the background. (C) Secondary electron image, hydrothermally in altered granite with sulfides (FAN-01-01) showing micrometric tubular La-Ce uranyl phosphate (Lan P) mat with smectite (Sme) sheets. (d) Backscattered electron image in hydrothermally altered granite with sulfides (FAN-01-01), showing sub-micrometric needles of uranyl sulfate minerals, associated to high local Th concentrations (U-sulfate + Th), in a jarosite (Jrs) and smectite assemblage. Mica is also identified in the background. (e) Backscattered electron image in hydrothermally altered sample (PEN-08-11) showing stellate micrometric needle aggregates of uranophane (Urp) covering the etched surface of calcite (Cal). (f)

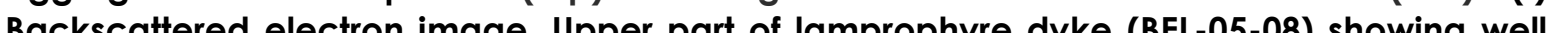




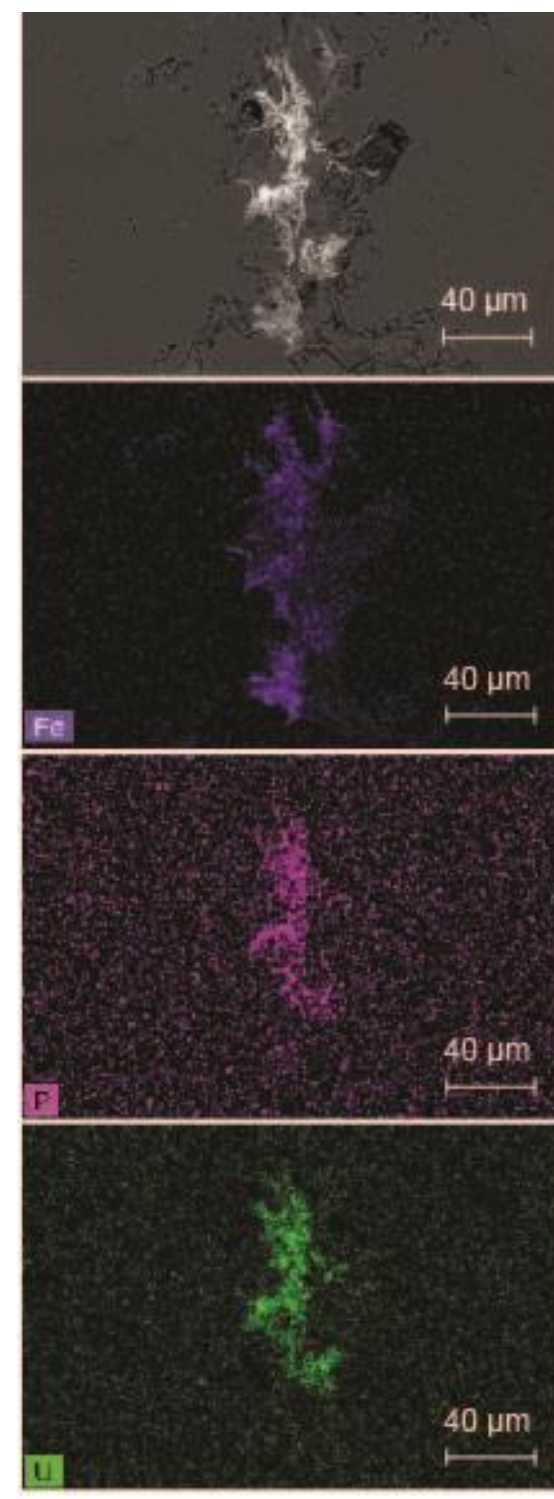

Fig. 6: SEM backscattered electrons image and EDS mapping (U, $P$ and Fe) in sample from sulfide-rich group (FAN-02-C1C). Fissure in quartz filled with uranyl phosphate and Fe oxide. 


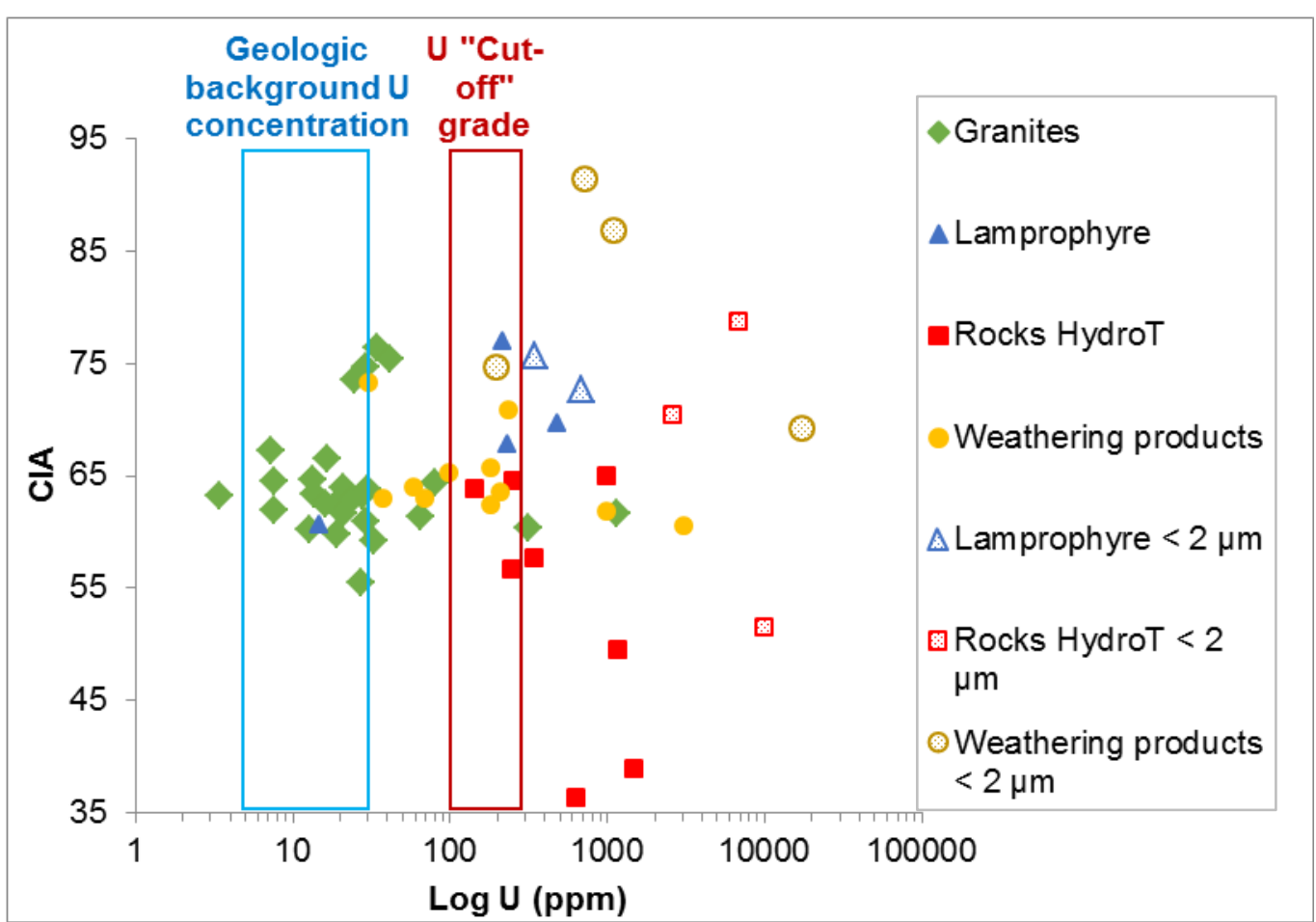

Fig. 7: Bivariate plot showing the evolution of CIA values with log $U$ concentrations. The same colors and symbols are used as in Figure 8. Blue and red frame were added to indicate, respectively, the Uranium concentration corresponding to the geological background ( 2 to $20 \mathrm{ppm}$ ) and the uranium concentration corresponding to the initial cut-off value (100 to 300 ppm). 


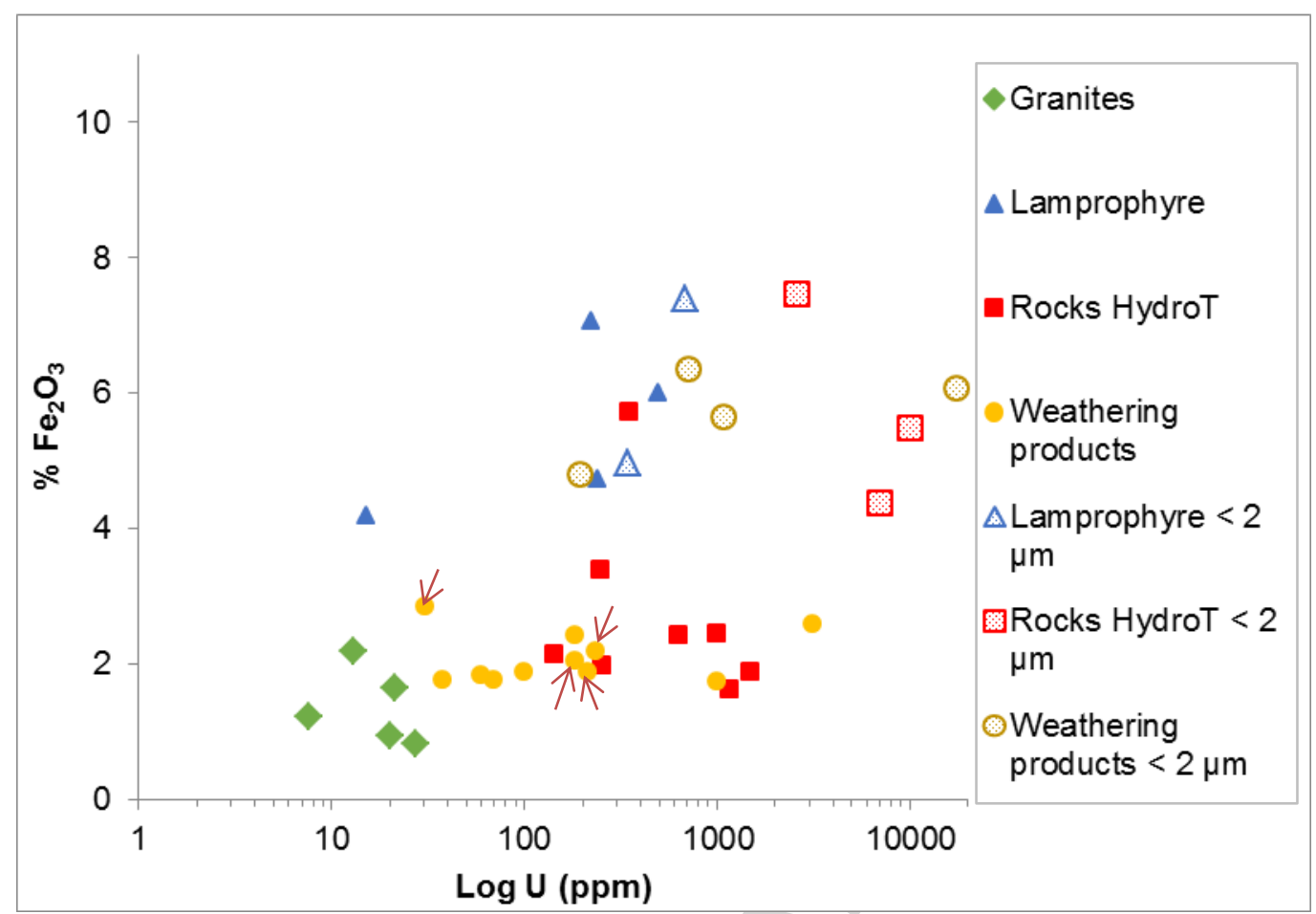

Fig. 8: Bivariate plot showing evolution of the $\mathrm{FFe}_{2} \mathrm{O}_{3}$ with $\mathrm{U}(\mathrm{ppm})$. The same colors and symbols are used as in Figure 8 . Bulk technosoil samples are indicated by arrows. 


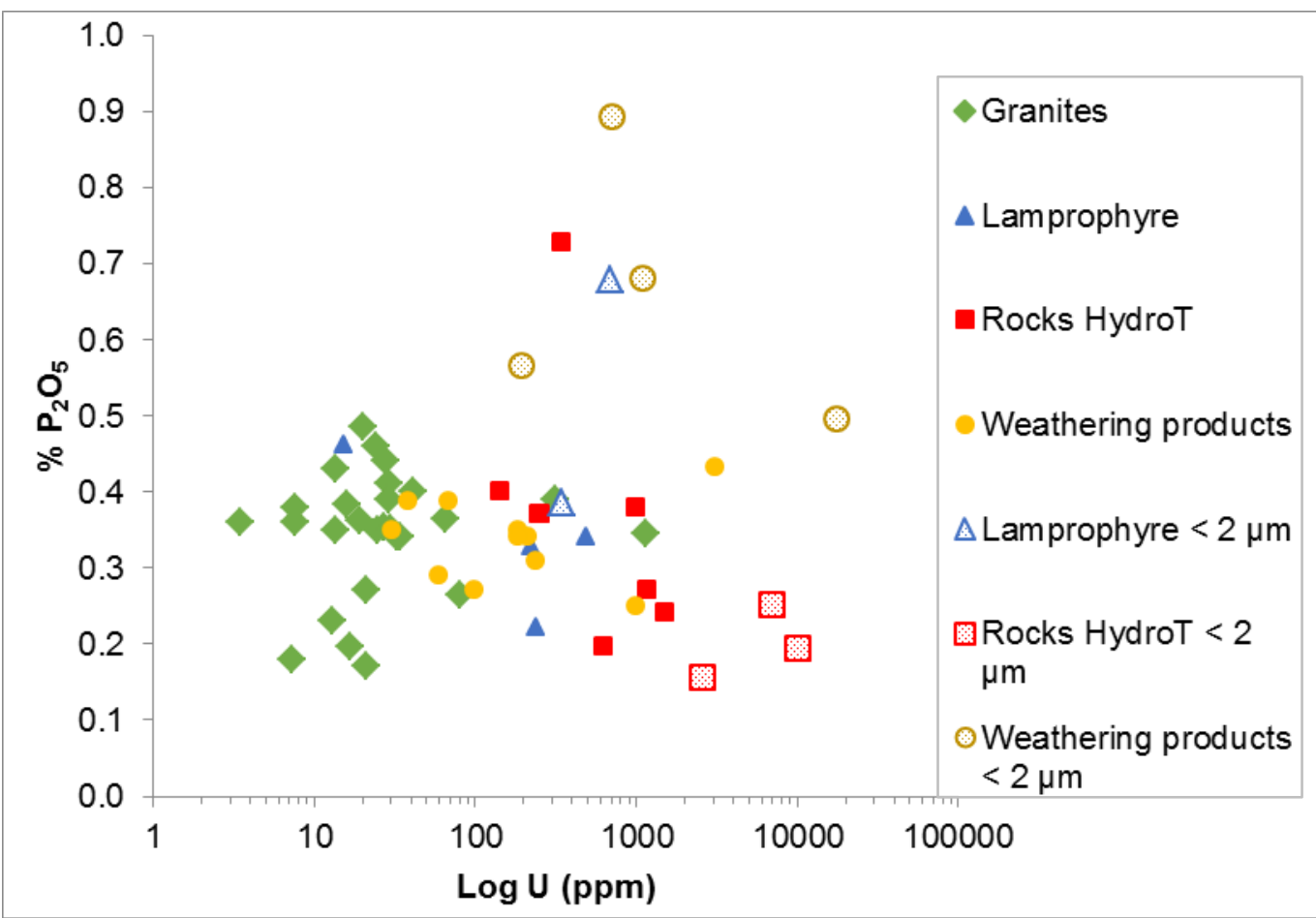

Fig. 9: Evolution of $\% \mathrm{P}_{2} \mathrm{O}_{5}$ with $\mathrm{U}(\mathrm{ppm})$. The same colors and symbols are used as in Figure 8. 
a)

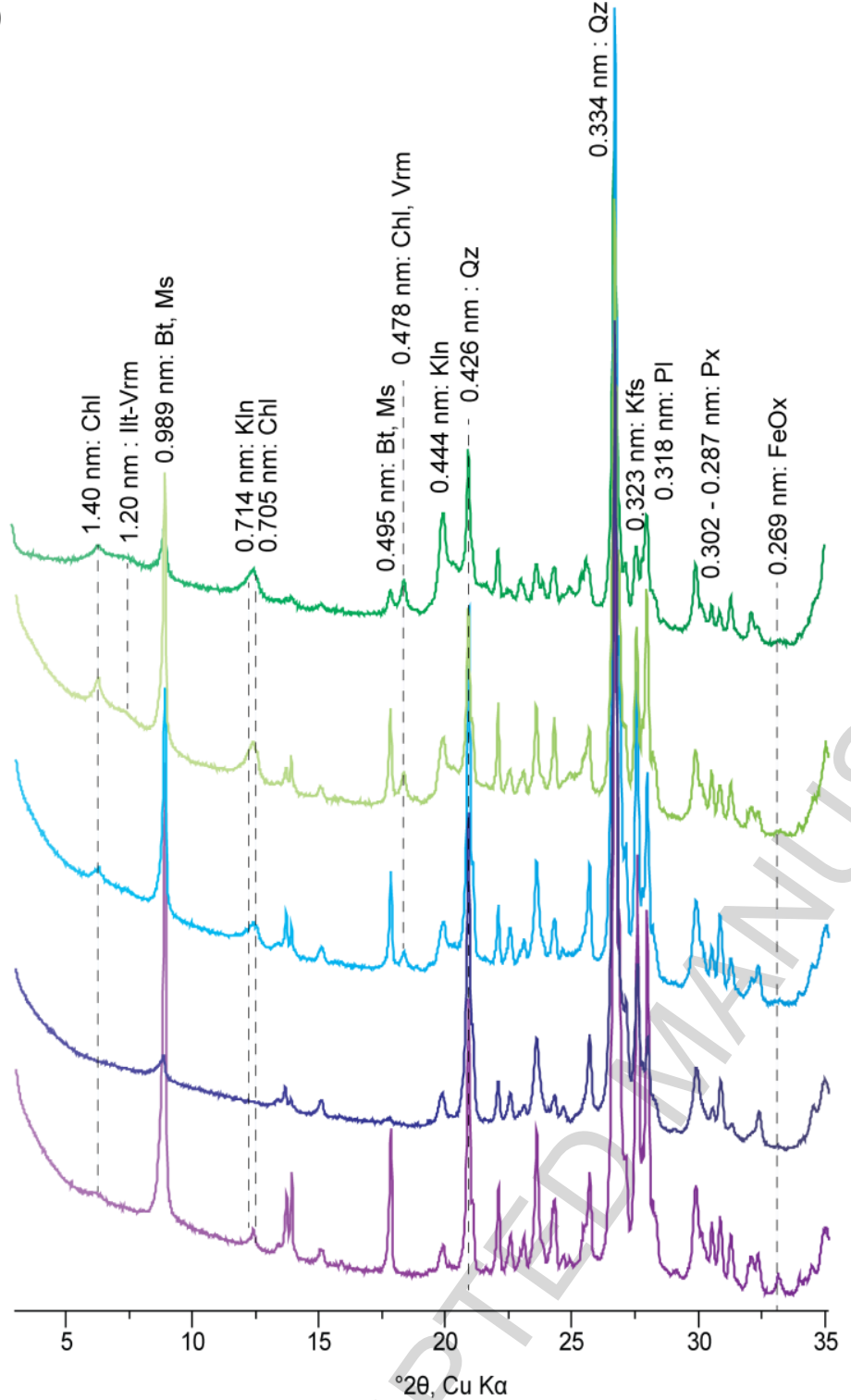

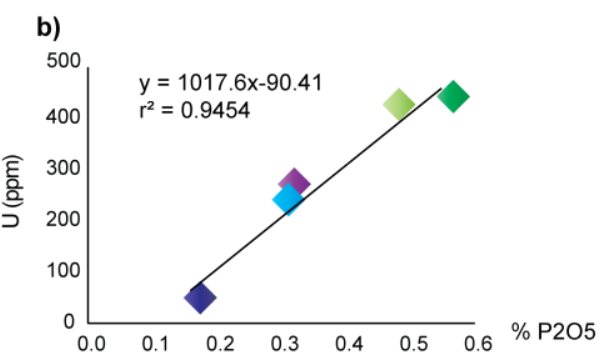

c)

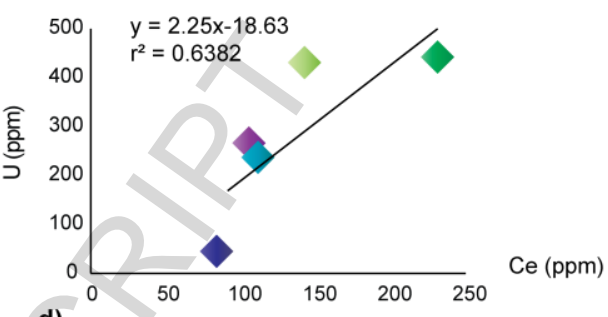

d)

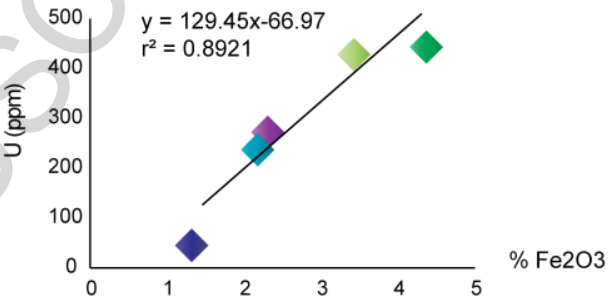

e)
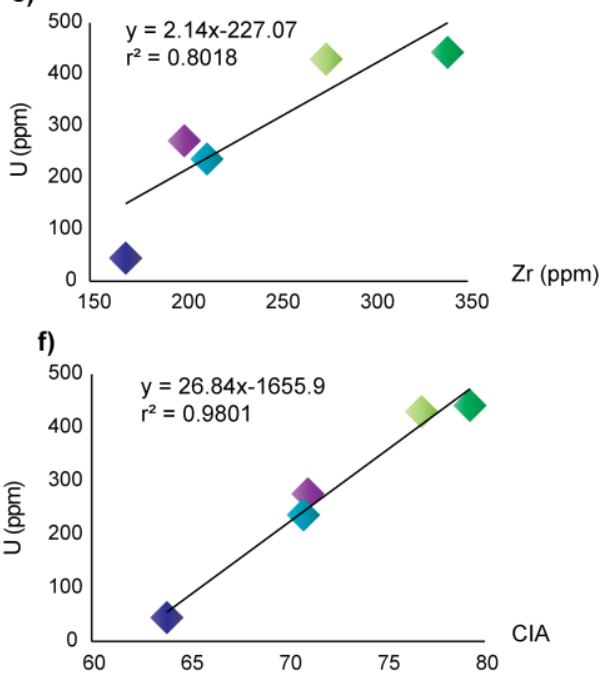

Fig. 10: Combined diffractograms and chemistry analyses results for the different granulometric fractions of one technosoil sample (FAN-02-C2). (a) DRX of different grain sizes, for the same technosoil sample, showing evolution of clay content from the gravel to the silt/clay fraction. Abbreviations translate as follows, Chl: chlorite, Ilt-Vrm: illite-vermiculite, Bt: biotite, Ms: muscovite, KIn; kaolinite, Qz: quartz, Kfs: K-feldspar, Pl: plagioclase, Px: pyroxene, FeOx: Fe oxide. (b) through (f) granulometric separation chemical analysis plots of $U$ against $\mathrm{Fe}_{2} \mathrm{O}_{3}, \mathrm{P}_{2} \mathrm{O}_{5}, \mathrm{Zr}$ and $\mathrm{Ce}$ and $\mathrm{CIA}$ values. 


\section{APPENDICES}

\section{Appendix A: Regional geological background}

The St-Sylvestre peraluminous leucogranitic complex was emplaced $\mathbf{3 2 4} \mathbf{M a}$ ago, as a part of the Variscan orogeny (Scaillet, 1996, and references therein). The most representative rocks are coarse to medium-grained, foliated, with $U$ concentrations ranging from 10 to $30 \mathrm{ppm}$. Those two-mica granites underwent a complex hydrothermal alteration history, including the formation of episyenites (columnar structures related dominantly to quartz dissolution):

- From 295 to $285 \mathbf{M a}$, lamprophyre intrusions crosscut the granitic bodies, during brittle fracture tectonic events (Rock 1984). "Lamprophyre dykes [...] contain augite, Mg-rich biotite, feldspar (potassic and/ or plagioclasic), pseudomorphs of minerals of the olivine group, apatite, and magnetite. In nearly all samples round quartz grain with a pyroxene rim can be observed. They are interpreted to be relicts of granitic material, partially assimilated by the lamprophyre magma (Velde, 1971)." (Leroy 1978). Lamprophyre intrusions cause the fluids to heat in the granitic massif fractures inducing hydrothermal alteration.

- Hydrothermal activity starting at $345^{\circ} \mathrm{C}$ induced the episyenitization of the granite, with formation of sulfides (pyrite, marcasite) and $U$ ore mineralization (pitchblende) dated at 284-274 Ma. U enrichment occurs up to $10 \mathrm{~m}$. from the ore vein (Ménager et al. 1992). The enriched zones are characterized by a gradient in sulfides and uranium ore minerals. Cooling of the system (from $330^{\circ} \mathrm{C}$ to $140^{\circ} \mathrm{C}$ ), after pitchblende deposition, induced formation of coffinite, hematite and marcasite. At temperatures below $135^{\circ} \mathrm{C}$ calcite, barite and fluorine minerals precipitated (Leroy 1978).

- Recent supergene alteration starts around 30 Ma ago (Leroy 1978). Ucontaining minerals are either related to the magmatic emplacement of the granite (mostly monazite, but also zircon and magmatic-stage uraninite), or to the hydrothermal mineralization (pitchblende and coffinite). Supergene alteration is thought to go as deep as $100 \mathrm{~m}$. (Cathelineau 1983) but is mainly located in the first $15 \mathrm{~m}$. (Barbier and Ranchin 1969). Products from supergene alteration are similar to intense weathering products, uraninite is dissolved and clay minerals, Fe oxides and autunites are formed. 

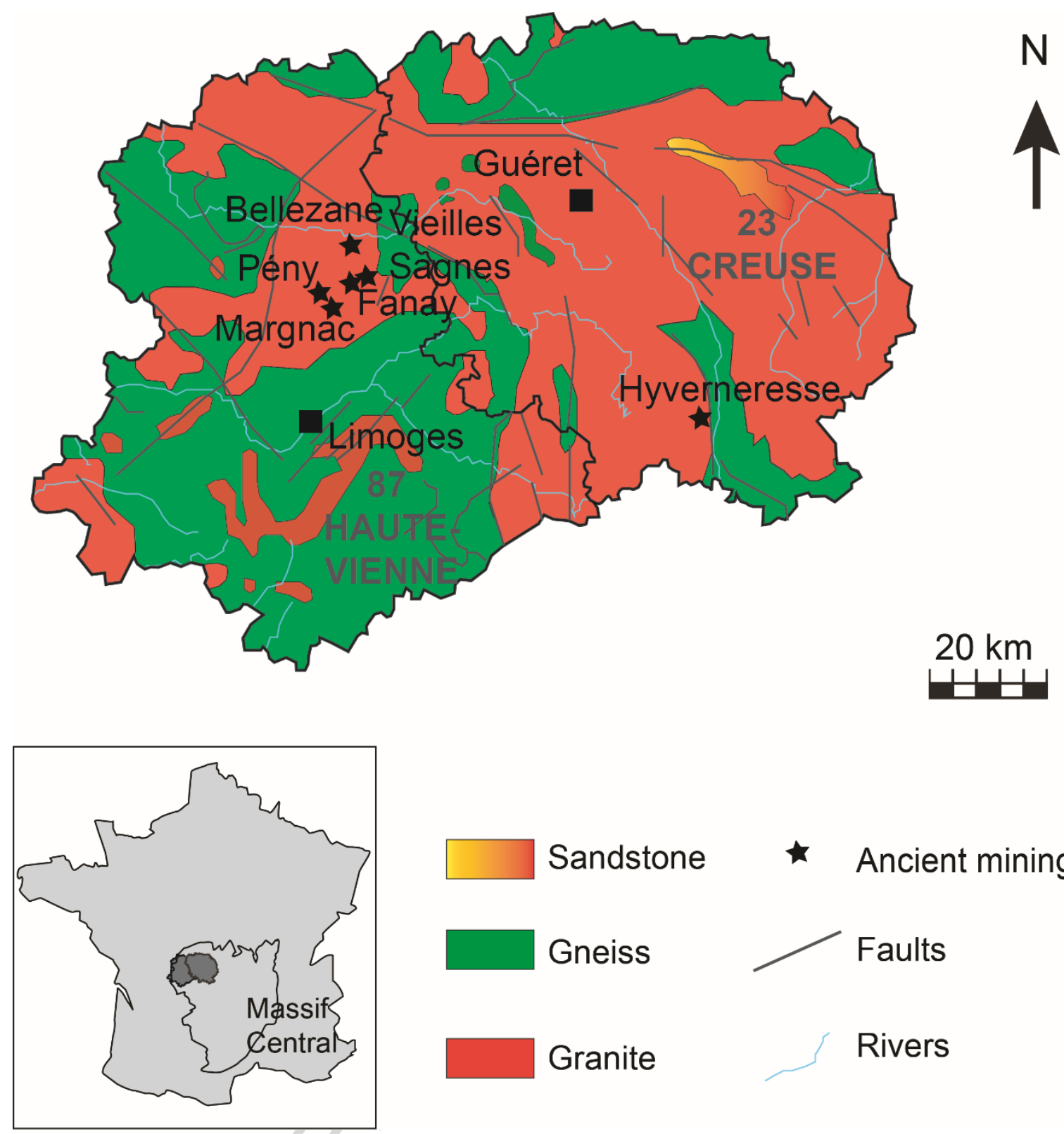

$\square$ Sandstone $\quad \star \quad$ Ancient mining site

Appendix B: Location of the former mining sites. 

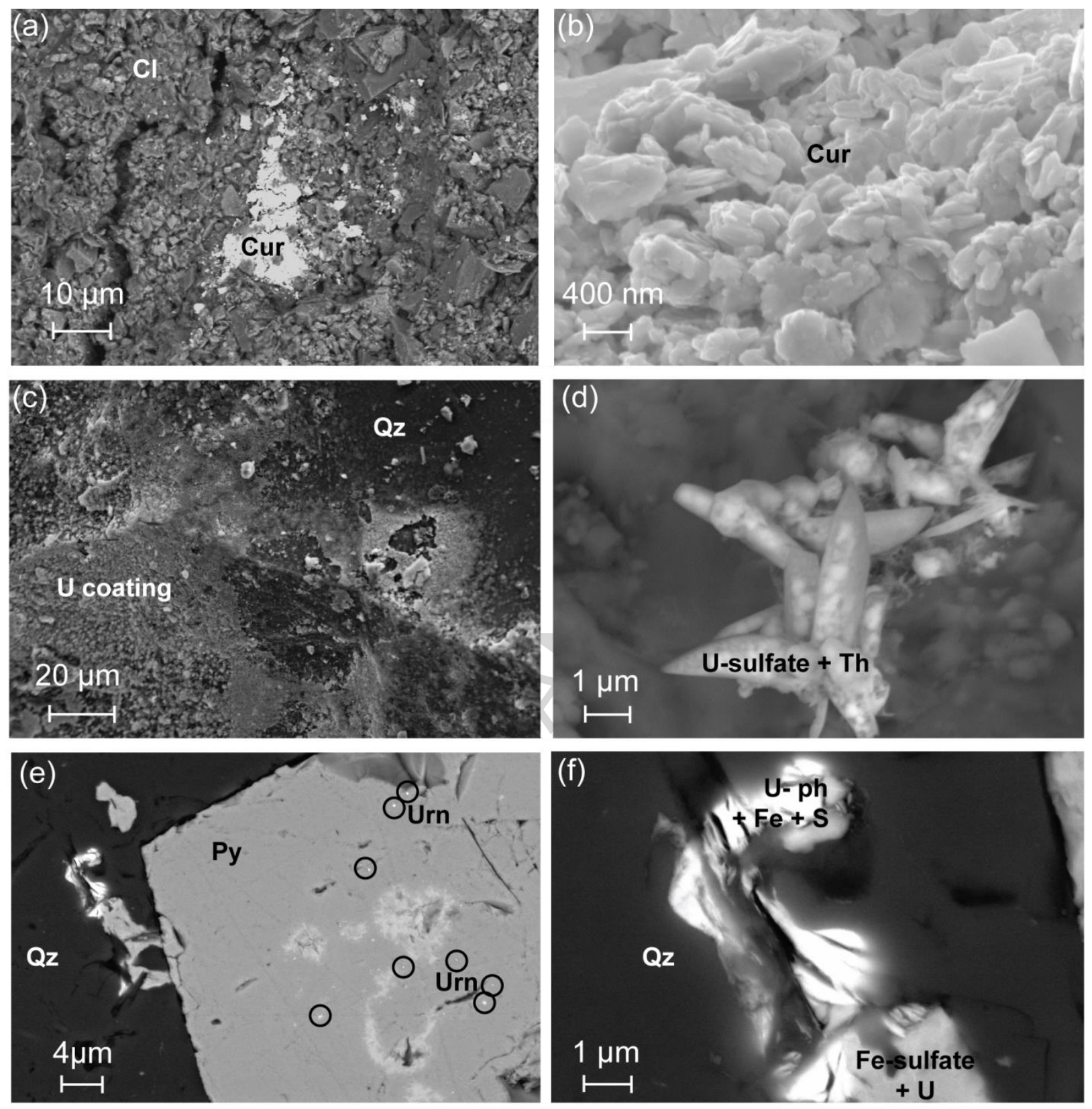

Appendix C: (a) Backscattered electron image in arenization matrix sample BEL-08-09, from Bellezane showing platy curite (Cur) crystals in clay mineral background. (b) Secondary electron image, close up from picture (a) platy shape of nanometric curite crystals is visible. (c) Secondary electron image, from hydrothermally altered granite PEN-08-11 showing Ucoating on quartz $(\mathrm{Qz})$ mineral. (d) Backscattered electron image of a similar mineral to the one in Fig. 5d, showing micrometric uranyl sulfates needles with Th local concentration (Usulfate+Th). Submicrometric particles (in brighter color in the needles) are associated to the needles. (e) Backscattered electron image from sulfide rich sample (FAN-02-C1C), showing nanometric uraninites (Urn), circled in black, in pyrite (Py). (f) Close up from (e) showing micrometric U-phosphate (U-ph) and Fe-sulfate in a fissure of a quartz mineral. Elements added (Fe, $S$ and $U$ ) are indicated because they were identified in the background. 


\section{Graphical abstract}
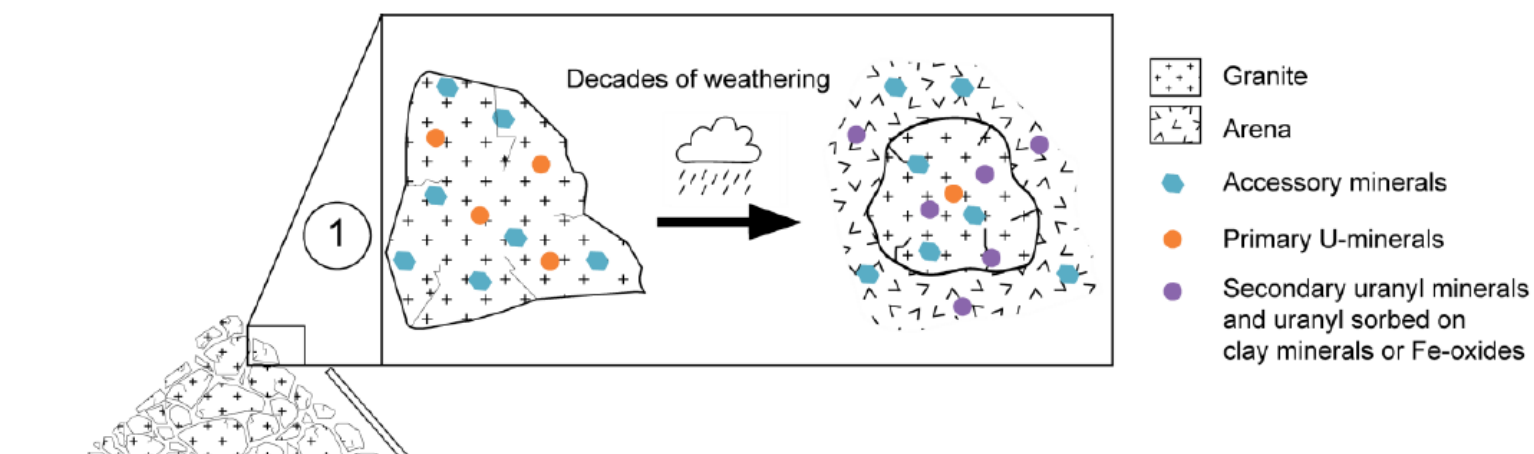

(2) Mechanical weathering, $U$ accumulation downslope in

- technosoils

- ferrihydrite pools

Waste rock pile 


\section{Highlights article:}

- Chemical Index of Alteration is efficiently applied to all samples on chaotic granitic waste rock pile for weathering assessment.

- Incipient weathering is noticeable in a time scale of decades.

- Diversity of secondary $U$ minerals is explained by previous geological history of the samples.

- Secondary $U$ mineral formed under oxidizing conditions is primarily uranylphosphate.

- Chemical and mechanical weathering combine and create U(VI) stabilization conditions under oxidizing environment. 